\title{
PROSES BISNIS DAN ASPEK PERPAJAKAN JASA PENUNJANG MINYAK DAN GAS BUMI UNTUK KEGIATAN USAHA JASA KONSTRUKSI (CONTENT ANALYSIS DAN HERMENEUTIC ANALYSIS)
}

\author{
Deddy Arief Setiawan \\ Direktorat Jenderal Pajak Kementerian Keuangan Republik Indonesia \\ deddy_arief@yahoo.com atau deddy.ariefsetiawan@gmail.com
}

\begin{abstract}
Revenue of Oil and Gas Income Tax increased by an average of 8.1 percent per year in the period 2006-2010. Oil and Gas Income Tax was produced by the oil and gas industry from upstream activities. The activity is a business activity that is high-risk exploration and production (exploitation). The success of these businesses should be supported by the supporting services of oil and gas. One of these supporting services is construction activity. The focus of this research is the business processes and taxation aspect for supporting services of oil and gas in construction activities. Based on this research focus, the discussion of this research consists of: 1). business process for supporting services of oil and gas in construction activities; and 2). taxation aspects for supporting services of the oil and gas in construction activities. The research methodology these was used a qualitative research approach with data analysis techniques of content analysis and hermeneutic Analyisis. Through content analysis and analyisis hermeneutic understanding of the laws and applicable these laws (law of oil and gas, law of construction services and law of taxation) can be done through a text interpretative with systematic and structured, so that can be generated explanation of business processes and taxation aspects for supporting services of the oil and gas in construction activities. Further data collection is done through field research and case study of taxation aspects for supporting services for oil and gas in construction activities. Business process for supporting services of the oil and gas in construction activity begins with an explanation of the construction services activity on law of construction services. Then proceed with the explanation of the construction services activities according to the law of oil and gas. The activity is one of supporting activities of oil and gas that the implementation is done in accordance with the law of construction services. The conclusion is business process for supporting services of the oil and gas in construction activities with the law of construction service and the law of oil and gas, are the same. However, that should be of particular concern is the Registered Certificate (SKT) from the Director of Engineering and Environmental for Oil and Gas. Taxation aspects for supporting services of the oil and gas in construction activities based on the law of income tax relating to the taxation of construction services that are similar to the taxation aspects for other than the supporting services of oil and gas. The conclusion is that the taxation aspects covering Income Tax Article 4 paragraph (2) shall be final and Income Tax Article 26 paragraph (4) for a Permanent Establishment (PE).
\end{abstract}

Keywords: The Supporting Service of Oil and Gas, Construction Service, Income Tax Article 4 paragraph (2), and Income Tax Article 26 paragraph (4).

Abstrak. Penerimaan Pajak Penghasilan Minyak dan Gas Bumi (PPh Migas) meningkat rata-rata 8,1 persen per tahun dalam periode 2006 - 2010. Pajak Penghasilan Minyak dan Gas Bumi dihasilkan oleh industri minyak dan gas bumi dari kegiatan usaha hulu. Kegiatan tersebut merupakan kegiatan bisnis yang melakukan eksplorasi yang berisiko tinggi dan melakukan produksi (eksploitasi). Keberhasilan kegiatan bisnis ini harus didukung oleh jasa penunjang minyak dan gas bumi. Salah satu jasa penunjang tersebut adalah kegiatan jasa konstruksi. Fokus penelitian ini adalah proses bisnis dan aspek perpajakan jasa penunjang minyak dan gas bumi untuk kegiatan jasa konstruksi. Berdasarkan pada fokus penelitian ini, maka pembahasan penelitian ini terdiri atas: 1) proses bisnis jasa penunjang minyak dan gas bumi untuk kegiatan jasa konstruksi; dan 2) aspek 
perpajakan jasa penunjang minyak dan gas bumi untuk kegiatan jasa konstruksi. Metodologi penelitian yang digunakan adalah pendekatan penelitian kualitatif dengan teknik analisis data content analysis (analisis isi) dan hermeneutic analyisis (analisis hermeneutika). Melalui content analysis dan hermeneutic analyisis pemahaman atas peraturan perundang-undang yang berlaku (Undang-Undang Minyak dan Gas Bumi, Undang-Undang Jasa Konstruksi dan Undang-Undang Perpajakan) dapat dilakukan melalui interpretatif teks secara sistematik dan terstruktur, sehingga dapat dihasilkan penjelasan proses bisnis dan aspek perpajakan jasa penunjang minyak dan gas bumi untuk kegiatan jasa konstruksi. Selanjutnya pengumpulan data penelitian dilakukan melalui pengamatan lapangan dan studi kasus atas aspek perpajakan jasa penunjang minyak dan gas bumi untuk kegiatan jasa konstruksi. Proses bisnis jasa penunjang minyak dan gas bumi untuk kegiatan jasa konstruksi diawali dengan penjelasan kegiatan usaha jasa konstruksi menurut undang-undang jasa konstruksi. Kemudian dilanjutkan dengan penjelasan kegiatan usaha jasa konstruksi menurut undang-undang minyak dan gas bumi. Kegiatan tersebut merupakan salah satu kegiatan usaha jasa penunjang minyak dan gas bumi yang pelaksanaannya dilakukan sesuai ketentuan peraturan perundang-undangan di bidang jasa konstruksi. Kesimpulannya adalah proses bisnis jasa penunjang minyak dan gas bumi untuk kegiatan jasa konstruksi menurut undang-undang jasa konstruksi dan undang-undang minyak dan gas bumi, adalah sama. Namun, yang perlu menjadi perhatian khusus adalah Surat Keterangan Terdaftar (SKT) dari Direktur Teknik dan Lingkungan Minyak dan Gas Bumi. Aspek perpajakan jasa penunjang minyak dan gas bumi untuk kegiatan jasa konstruksi berdasarkan undang-undang perpajakan terkait dengan jasa konstruksi sehingga aspek perpajakan tersebut sama dengan aspek perpajakan selain jasa penunjang minyak dan gas bumi. Kesimpulannya adalah aspek perpajakan tersebut meliputi Pajak Penghasilan Pasal 4 ayat (2) bersifat final dan Pajak Penghasilan Pasal 26 ayat (4) bagi Bentuk Usaha Tetap (BUT).

Kata Kunci: Jasa Penunjang Minyak dan Gas Bumi, Jasa Konstruksi, Pajak Penghasilan Pasal 4 Ayat (2), dan Pajak Penghasilan Pasal 26 Ayat (4).

Direktorat Jenderal Pajak telah membentuk Kantor Pelayanan Pajak (KPP) khusus menangani industri minyak dan gas bumi sesuai dengan Peraturan Menteri Keuangan Nomor 29/PMK.01/2012 tentang Perubahan atas Peraturan Menteri Keuangan Nomor 62/PMK.01/2009 tentang Organisasi dan Tata Kerja Instansi Vertikal Direktorat Jenderal Pajak. Tujuan utamanya adalah guna menggali penerimaan perpajakan yang lebih besar dari sektor usaha potensial seperti industri minyak dan gas bumi, dan memberikan pelayanan serta pengawasan yang lebih optimal kepada industri minyak dan gas bumi yang telah memberikan kontribusi penerimaan kepada negara berupa Pajak Penghasilan Minyak dan Gas Bumi (PPh Migas). Menurut Nota keuangan APBN Tahun 2012 (www.kemenkeu.go.id) penerimaan $\mathrm{PPh}$ migas meningkat rata-rata 8,1 persen per tahun dalam periode tahun 2006 - 2010, terutama dipengaruhi oleh perkembangan ICP dan realisasi lifting. Penerimaan tersebut terdiri atas $\mathrm{PPh}$ minyak bumi dan $\mathrm{PPh}$ gas alam yang masing-masing memberikan kontribusi rata-rata sebesar 37,0 persen dan 63,0 persen. Komposisi penerimaan PPh Migas tahun 2010 dan 2011 dapat dilihat pada tabel 1 dan perkembangan realisasi PPh Migas periode 2006 s.d. 2011 dapat dilihat pada tabel 2.

Kantor Pelayanan Pajak Minyak dan Gas Bumi hanya menggantikan nama Kantor Pelayanan Pajak Badan dan Orang Asing Dua. Wajib Pajak yang diadministrasikan oleh KPP Minyak dan Gas Bumi adalah Wajib Pajak yang melakukan kegiatan hulu minyak dan gas bumi beserta kegiatan penunjangnya. Status Wajib Pajak yang diadministrasikan berbentuk Wajib Pajak Badan Dalam Negeri seperti Perseroan Terbatas (PT) dan Wajib Pajak Luar Negeri seperti Bentuk Usaha Tetap (BUT). Berdasarkan Buku Panduan Kantor Pelayanan Pajak Minyak dan Gas Bumi (Penulis sebagai salah satu Team KPP Minyak dan Gas Bumi); Proses Bisnis dan Aspek Perpajakan (Team KPP Minyak dan Gas Bumi, 2012: iv) dan slide "Overview KPP Migas" oleh Bapak Dewa Made Budiarta (2012) yang materi slide-nya telah disesuaikan dengan Buku Panduan Kantor 
Tabel 1. Penerimaan PPh Migas Periode 2010-2011

triliun Rp

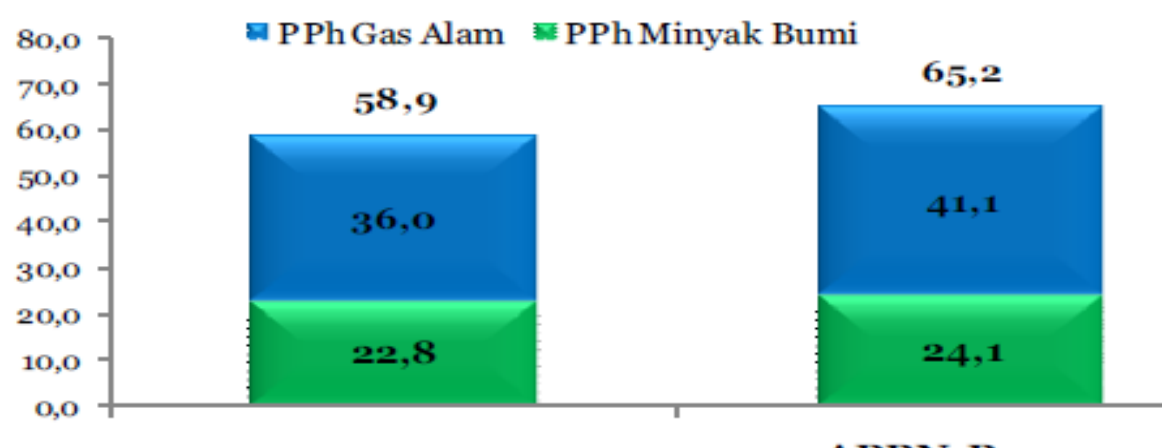

2010

APBN-P 2011

Sumber : Kementerian Keuangan

Tabel 2. perkembangan realisasi PPh Migas Periode 2006 s.d. 2011 (dalam triliun rupiah) *)

\begin{tabular}{|c|c|c|c|c|c|c|c|c|c|c|c|c|}
\hline \multirow[b]{2}{*}{ Uraian } & \multicolumn{2}{|c|}{2006} & \multicolumn{2}{|c|}{2007} & \multicolumn{2}{|c|}{2008} & \multicolumn{2}{|c|}{2009} & \multicolumn{2}{|c|}{2010} & \multicolumn{2}{|c|}{2011} \\
\hline & Real. & $\begin{array}{l}\% \text { thd } \\
\text { Total }\end{array}$ & Real. & $\begin{array}{l}\text { \%thd } \\
\text { Total }\end{array}$ & Real. & $\begin{array}{l}\text { \% thd } \\
\text { Total }\end{array}$ & Real. & $\begin{array}{l}\text { \% thd } \\
\text { Total }\end{array}$ & Real. & $\begin{array}{l}\text { \% thd } \\
\text { Total }\end{array}$ & APBN-P & $\begin{array}{l}\text { \% thd } \\
\text { Total }\end{array}$ \\
\hline PPh Minyak Bumi & 14,7 & 34,0 & 16,3 & 37,0 & 29,6 & 38,5 & 18,4 & 36,7 & 22,8 & 38,8 & 24,1 & 37,0 \\
\hline PPh Gas Alam & 28,5 & 66,0 & 27,3 & 62,0 & 47,4 & 61,5 & 31,7 & 63,3 & 36,0 & 61,2 & 41,1 & 63,0 \\
\hline PPh Migas Lainnya & 0,0 & 0,0 & 0,4 & 1,0 & 0,0 & 0,0 & 0,0 & 0,0 & 0,0 & 0,0 & 0,0 & 0,0 \\
\hline Total & 43,2 & 100,0 & 44,0 & 100,0 & 77,0 & 100,0 & 50,0 & 100,0 & 58,9 & 100,0 & 65,2 & 100,0 \\
\hline
\end{tabular}

*) Perbedaan angka di belakang koma karena pembulatan

Sumber: Kementerian Keuangan

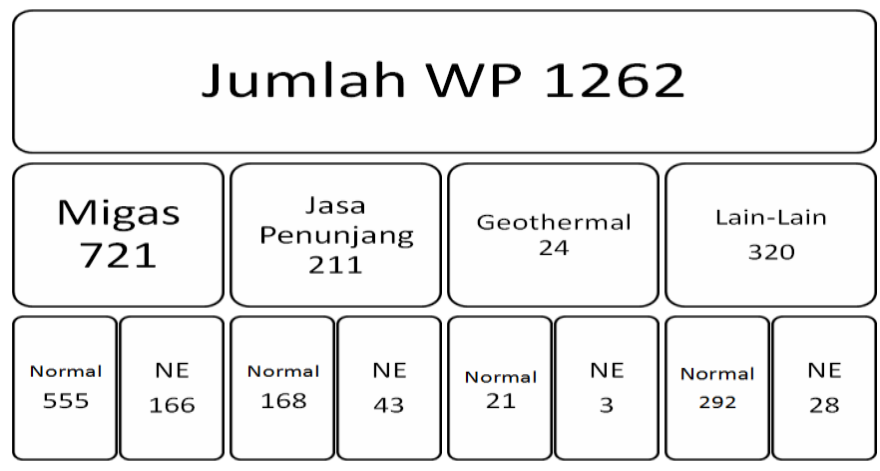

\begin{tabular}{|c|c|c|c|c|c|}
\hline \multicolumn{6}{|c|}{ WP Migas 555} \\
\hline \multicolumn{3}{|c|}{$\begin{array}{c}\text { Operator } \\
253\end{array}$} & \multicolumn{2}{|c|}{$\begin{array}{c}\text { Silent } \\
\text { Partner } \\
296\end{array}$} & $\begin{array}{c}\text { Rep. } \\
\text { Off } \\
6\end{array}$ \\
\hline $\begin{array}{l}\text { BUT } \\
189\end{array}$ & $\begin{array}{l}\text { PT } \\
43\end{array}$ & $\begin{array}{l}10 \\
21\end{array}$ & $\begin{array}{l}\text { Buf } \\
233\end{array}$ & $\begin{array}{l}\mathrm{PT} \\
62\end{array}$ & $\begin{array}{c}\text { BUT } \\
6\end{array}$ \\
\hline
\end{tabular}

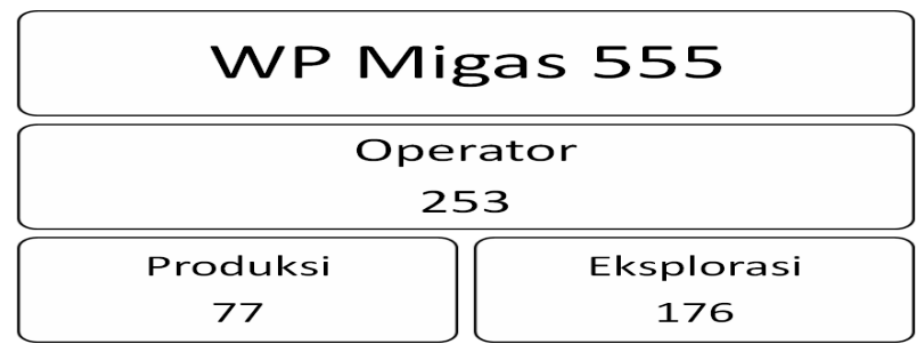




\section{WP Jasa Penunjang 168}

\begin{tabular}{|c|c|c|c|c|c|c|c|c|}
\hline \multicolumn{2}{|c|}{$\begin{array}{c}\text { Drilling } \\
91\end{array}$} & \multicolumn{2}{|c|}{$\begin{array}{c}\text { Seismic } \\
19\end{array}$} & \multicolumn{2}{|c|}{$\begin{array}{c}\text { Konstruksi } \\
40\end{array}$} & $\begin{array}{c}\text { Transportasi } \\
1\end{array}$ & \multicolumn{2}{|c|}{$\begin{array}{c}\text { Lain-Lain } \\
17\end{array}$} \\
\hline $\begin{array}{c}\text { BUT } \\
34\end{array}$ & $\begin{array}{l}\mathrm{PT} \\
57\end{array}$ & $\begin{array}{c}\text { BUT } \\
1\end{array}$ & $\begin{array}{l}\text { PT } \\
18\end{array}$ & $\begin{array}{c}\text { BUT } \\
5\end{array}$ & $\begin{array}{l}\mathrm{PT} \\
35\end{array}$ & $\begin{array}{c}\text { PT } \\
1\end{array}$ & $\begin{array}{c}\text { BUT } \\
5\end{array}$ & $\begin{array}{l}\mathrm{PT} \\
12\end{array}$ \\
\hline
\end{tabular}

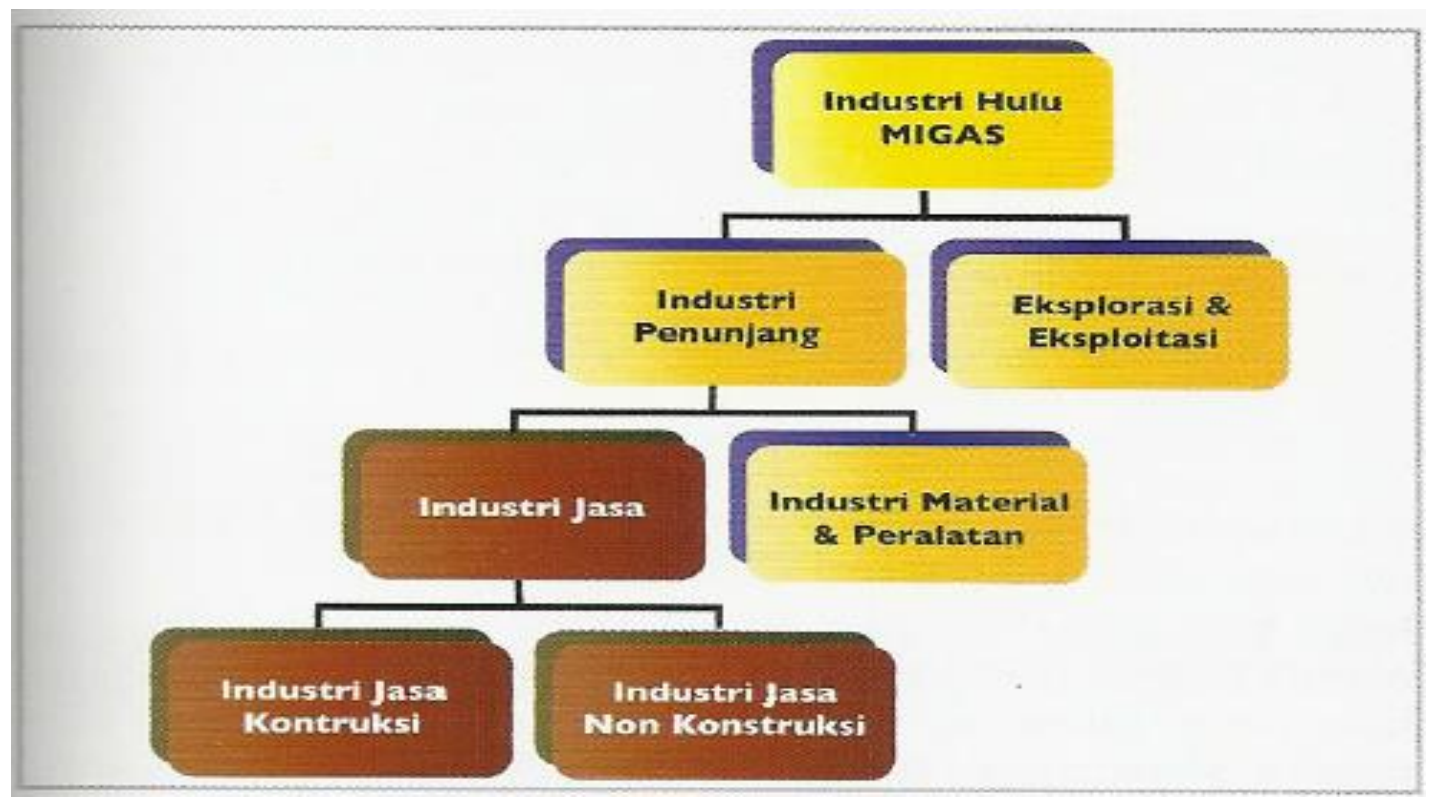

Pelayanan Pajak Minyak dan Gas Bumi, KPP Minyak dan Gas Bumi beroperasi mulai sejak 2 April 2012 dan ditetapkan jumlah Wajib Pajak yang terdaftar di KPP Minyak dan Gas Bumi yaitu sebanyak 1.262 Wajib Pajak dengan komposisi sebagai berikut:

Dari jumlah Wajib Pajak Normal yang bergerak di bidang pertambangan dan gas bumi sebanyak 561 Wajib Pajak dan jasa penunjang sebanyak 170 Wajib Pajak yang terdaftar di KPP Minyak dan Gas Bumi menurut Team KPP Minyak dan Gas Bumi (2012: iv-v) dan Dewa Made Budiarta (2012) yang materi slidenya telah disesuaikan dengan Buku Panduan Kantor Pelayanan Pajak Minyak dan Gas Bumi, dapat dibedakan sebagai berikut: Industri minyak dan gas bumi meliputi dua kegiatan usaha yaitu, kegiatan usaha inti dan kegiatan usaha penunjang minyak dan gas bumi. Menurut Rudi Rubiandini R.S. (2010: 58-59), salah satu kegiatan usaha inti adalah kegiatan usaha hulu dan didukung oleh salah satu kegiatan usaha penunjang dibidang Jasa Konstruksi atau Kontraktor. Kegiatan usaha hulu merupakan kegiatan bisnis yang melakukan eksplorasi yang berisiko tinggi dan melakukan produksi (eksploitasi). Keberhasilan kegiatan bisnis ini harus didukung oleh jasa penunjangnya. Menurut Rudi Rubiandini R.S. (2010: 67), industri minyak dan gas bumi dapat digambarkan di bawah ini:

\section{Fokus dan Tujuan Penelitian}

Fokus penelitian yang dilakukan adalah proses bisnis dan aspek perpajakan jasa penunjang minyak dan gas bumi untuk kegiatan jasa konstruksi. Pekerjaan konstruksi menyentuh segala aspek perundang-undangan yang berlaku. Pelaku bisnis usaha jasa konstruksi seharusnya mengetahui perundang- 
undangan yang berlaku sehingga usahanya dapat tumbuh dan berkembang tanpa terkendala adanya aturan-aturan yang berlaku tersebut. Umumnya kegiatan usaha jasa konstruksi tersebut hanya menyentuh yuridis undangundang jasa konstruksi dan undang-undang perpajakan. Apabila usaha jasa konstruksi dibidang minyak dan gas bumi, yuridis yang menyentuh usaha tersebut adalah, undangundang minyak dan gas bumi, undang-undang jasa konstruksi dan undang-undang perpajakan.

Pembahasan penelitian pertama adalah proses bisnis jasa penunjang minyak dan gas bumi untuk kegiatan jasa konstruksi. Proses bisnis tersebut berdasarkan tinjuan yuridis tentang kegiatan usaha jasa konstruksi terkait dengan undang-undang minyak dan gas bumi dan undang-undang jasa konstruksi. Tujuan penelitian adalah agar pelaku bisnis usaha jasa konstruksi dibidang minyak dan gas bumi tidak melanggar perundang-undangan yang berlaku dan mengetahui awal proses kegiatannya yang harus dilakukannya. Pembahasan penelitian kedua adalah kajian aspek perpajakan atas jasa penunjang minyak dan gas bumi untuk kegiatan jasa konstruksi yang berdasarkan undangundang perpajakan. Kedua pembahasan tersebut menggunakan teknik analisis data content analysis dan hermeneutic analyisis. Content analysis (analisi isi) adalah analisis yang didasarkan pada isi dokumen tertulis, baik berupa peraturan, surat kabar maupun catatan harian (Tim Penyusun STIAMI, 2012: 56). Hermeneutic analysis (analisis hermeneutika) adalah analisis yang ditujukan pada interpretasi tekstual, atau menemukan makna pada setiap kata atau kalimat (Tim Penyusun STIAMI, 2012: 56).

\section{KAJIAN LITERATUR}

\section{Undang-Undang Minyak dan Gas Bumi}

Kegiatan jasa konstruksi di bidang minyak dan gas bumi telah diatur oleh beberapa ketentuan peraturan perundang-undangan yang berlaku terdiri atas: 1) Memori penjelasan Pasal 39 ayat (1) huruf a Undang-undang Nomor 22 Tahun 2001 tentang Minyak dan Gas Bumi, diatur bahwa penyelenggaraan urusan pemerintah yang dimaksud dalam ketentuan ini meliputi antara lain: penyebarluasan informasi, pendidikan dan pelatihan, penelitian dan pengembangan teknologi, peningkatan nilai tambah produk, penerapan standardisasi, pemberian akreditasi, pembinaan industri/badan usaha penunjang, pembinaan usaha kecil/menengah, pemanfaatan barang dan jasa dalam negeri, pemeliharaan keselamatan dan kesehatan kerja, pelestarian lingkungan hidup, penciptaan iklim investasi yang kondusif, serta pemeliharaan keamanan dan ketertiban; 2) Pasal 87 ayat (1) Peraturan Pemerintah Nomor 55 Tahun 2009 tentang Perubahan Kedua Atas Peraturan Pemerintah Nomor 35 Tahun 2004 tentang Kegiatan Usaha Hulu Minyak dan Gas Bumi, diatur bahwa penyelenggaraan urusan pemerintah yang dibidang Kegiatan Usaha Hulu sebagiamana dimaksud dalam pasal 86 ayat (2) huruf a meliputi: a) perencanaan, b) perizinan, persetujuan, dan rekomendasi, c) pengelolaan dan pemanfaatan Data Minyak dan Gas Bumi, d) pendidikan dan pelatihan, e) penelitian dan pengembangan teknologi, f) penerapan standardisasi, g) pemberian akreditasi, h) pemberian sertifikasi, i) pembinaan industri/ badan usaha penunjang, $\mathrm{j}$ ) pembinaan usaha kecil/menengah, $\mathrm{k}$ ) pemanfaatan barang dan jasa dalam negeri, 1) pemeliharaan keselamatan dan kesehatan kerja, m) pelestarian lingkungan hidup, n) penciptaan iklim investasi yang kondusif, o) pemeliharaan keamanan dan ketertiban; 3) Peraturan Menteri Energi dan Sumber Daya Mineral Nomor 27 Tahun 2008 tentang Kegiatan Usaha Penunjang Minyak dan Gas Bumi, diatur bahwa: a) Pasal 1 angka 5, usaha jasa konstruksi minyak dan gas bumi adalah kegiatan usaha jasa layanan untuk penanganan pekerjaan bangunan atau konstruksi atau wujud fisik lainnya dalam menunjang kegiatan usaha Minyak dan Gas Bumi, b) Pasal 5 ayat (2), Bidang Usaha Jasa Konstruksi Migas se-bagaimana dimaksud pada ayat (1) huruf a terdiri dari: a) Usaha Jasa Perencanaan Konstruksi termasuk rancang bangun dan rekayasa (design engineering), b) Usaha Jasa Pelaksanaan Konstruksi termasuk Engineering, Procurement, and Construction (EPC), usaha instalasi, dan komisioning, dan c) Usaha Jasa Pengawasan Konstruksi,yang pelaksanaannya dilakukan sesuai ketentuan 
peraturan perundang-undangan di bidang jasa konstruksi; 4) Keputusan Direktur Jenderal Minyak Dan Gas Bumi Nomor 15784.K/10/DJM.S/2010 tanggal 25 Juni 2010 tentang Pedoman Pemberian Surat Keterangan Terdaftar. Surat Keterangan Terdaftar tersebut merupakan surat yang diberikan kepada perusahaan atau perseorangan yang melaksanakan usaha penunjang minyak dan gas bumi seperti usaha jasa konstruksi minyak dan gas bumi, berdasarkan klasifikasi usaha penunjang sesuai dengan kompetensi yang dimiliki.

Landasan hukum kegiatan usaha jasa konstruksi sebagai kegiatan usaha penunjang minyak dan gas bumi sangat jelas diatur dalam Peraturan Menteri Energi dan Sumber Daya Mineral Nomor 27 Tahun 2008 dan pembinaannya sebagai badan usaha penunjang minyak dan gas bumi oleh pemerintah diatur dalam Undang-undang Nomor 22 Tahun 2001 dan Peraturan Pemerintah Nomor 55 Tahun 2009. Kemudian penilaian kualifikasinya diatur dalam Keputusan Direktur Jenderal Minyak dan Gas Bumi Nomor 15784.K/10/DJM.S/2010 tanggal 25 Juni 2010.

Berikut ini bagan ketentuan kegiatan usaha jasa konstruksi menurut undang-undang minyak dan gas bumi.

\section{Undang-Undang Jasa Konstruksi}

Pelaksanaan kegiatan usaha jasa konstruksi dibidang minyak dan gas bumi dilakukan sesuai ketentuan peraturan perundang-undangan di bidang jasa konstruksi sehingga ketentuan undang-undang jasa konstruksi mengatur kegiatan usaha jasa konstruksi dibidang minyak dan gas bumi maupun kegiatan usaha jasa konstruksi pada umumnya, yang meliputi: 1) Pasal 34 Undang-undang Nomor 18 Tahun 1999 tentang Jasa Konstruksi, diatur bahwa ketentuan mengenai forum sebagaimana dimaksud dalam Pasal 32 dan lembaga sebagaimana dimaksud dalam Pasal 33 diatur lebih lanjut dengan Peraturan Pemerintah; 2) Peraturan Pemerintah Nomor 92 Tahun 2010 tentang Perubahan Kedua atas Peraturan Pemerintah Nomor 28 Tahun 2000 tentang Usaha dan Peran Masyarakat Jasa Konstruksi, diatur bahwa: a) Pasal 1 angka 1, Lembaga adalah organisasi sebagaimana dimaksud dalam Undang-undang Nomor 18 Tahun 1999 tentang Jasa Konstruksi, yang bertujuan untuk mengem-bangkan kegiatan jasa konstruksi nasional, b) Pasal 24 ayat (1), untuk melaksanakan kegiatan pengembangan jasa konstruksi didirikan Lembaga Pengembangan Jasa Konstruksi yang selanjutnya disebut Lembaga, c) Pasal 24 ayat (2), Lembaga sebagaimana dimaksud pada ayat (1) terdiri atas: (1) Lembaga Tingkat Nasional, yang berkedudukan di ibu kota negara; (2) Lembaga Tingkat Provinsi, yang berkedudukan di ibu kota provinsi; 3) Pasal 3 Peraturan Lembaga Pengembangan Jasa Konstruksi Nomor 02 Tahun 2011 tentang Tata Cara Registrasi Ulang, Perpanjangan Masa Berlaku, dan Permohonan Baru Sertifikat Badan Usaha Jasa Pelaksana Konstruksi, diatur bahwa lingkup pengaturan ini tentang tata cara registrasi ulang Jasa Pelaksana Konstruksi untuk SBU yang masih berlaku, perpanjangan SBU yang telah habis masa berlakunya dan permohonan baru SBU meliputi ketentuan tentang bentuk, sifat, persyaratan, dan penggolongan kualifikasi usaha jasa pelaksana konstruksi, penyelenggaraan registrasi, penyelenggaraan sertifikasi dan persyaratan permohonan sertifikasi; 4) Pasal 3 Peraturan Lembaga Pengembangan Jasa Konstruksi Nomor 03 Tahun 2011 tentang Tata Cara Registrasi Ulang, Perpanjangan Masa Berlaku dan Permohonan Baru Sertifikat Badan Usaha Jasa Perencana dan Pengawas Konstruksi, diatur bahwa lingkup pengaturan ini tentang tata cara registrasi ulang Jasa Perencana Konstruksi dan Jasa Pengawas Konstruksi untuk SBU yang masih berlaku, perpanjangan SBU yang telah habis masa berlakunya dan permohonan baru SBU meliputi ketentuan tentang bentuk, sifat, persyaratan, dan penggolongan kualifikasi usaha jasa perencana konstruksi dan jasa pengawas konstruksi, penyelenggaraan registrasi, penyelenggaraan sertifikasi dan persyaratan permohonan sertifikasi; 5) Pasal 2 Peraturan Menteri Pekerjaan Umum Nomor 04/PRT/M/2011 tentang Pedoman Persyaratan Pemberian Izin Usaha Jasa Konstruksi Nasional, diatur bahwa Peraturan Menteri ini dimaksudkan sebagai pedoman bagi 
Pemerintah kabupaten/kota dalam memberikan IUJK dengan tujuan untuk melindungi kepentingan masyarakat dan pembinaan dibidang jasa konstruksi; 6) Peraturan Menteri Pekerjaan Umum Nomor 05/PRT/M/2011 tentang Pedoman Persyaratan Pemberian Izin Perwakilan Badan Usaha Jasa Konstruksi Asing, diatur bahwa: a) Pasal 2, Peraturan Menteri ini dimaksudkan sebagai pedoman bagi Pemerintah kabupaten/kota dalam memberikan IUJK dengan tujuan untuk melindungi kepentingan masyarakat dan pembinaan dibidang jasa konstruksi, b) Pasal 3, lingkup pengaturan dalam Peraturan Menteri ini meliputi kegiatan jasa konstruksi yang dilakukan oleh BUJKA di wilayah Indonesia.

Landasan hukum jasa konstruksi sangat jelas diatur dalam Undang-undang Nomor 18 Tahun 1999 dan Peraturan Pemerintah Nomor 92 Tahun 2010, yang petunjuk pelaksanaannya diatur dalam Peraturan Lembaga Pengembangan Jasa Konstruksi Nomor 02 Tahun 2011 untuk Sertifikat Badan Usaha Jasa Pelaksana Konstruksi, Peraturan Lembaga Pengembangan Jasa Konstruksi Nomor 03 Tahun 2011 untuk Sertifikat Badan Usaha Jasa Perencana dan Pengawas Konstruksi, Peraturan Menteri Pekerjaan Umum nomor 04/PRT/M/2011 untuk pemberian izin usaha jasa konstruksi nasional, dan Peraturan Menteri Pekerjaan Umum nomor 05/PRT/M/2011 untuk pemberian izin perwakilan badan usaha jasa konstruksi asing. Berikut ini bagan ketentuan kegiatan usaha jasa konstruksi menurut undangundang jasa konstruksi.

\section{Undang-Undang Perpajakan}

Ketentuan peraturan perpajakan mengenai kegiatan jasa konstruksi yang harus dilaksanakan adalah sebagai berikut: 1) Pasal 4 ayat (2) Undang-Undang Nomor 7 Tahun 1983 tentang Pajak Penghasilan sebagaimana telah beberapa kali diubah terakhir dengan UndangUndang Nomor 36 Tahun 2008, diatur bahwa Penghasilan di bawah ini dapat dikenai pajak bersifat final: a) penghasilan berupa bunga deposito dan tabungan lainnya, bunga obligasi dan surat utang negara, dan bunga simpanan yang dibayarkan oleh koperasi kepada anggota koperasi orang pribadi, b) penghasilan berupa hadiah undian, c) penghasilan dari transaksi saham dan sekuritas lainnya, transaksi derivatif yang diperdagangkan di bursa, dan transaksi penjualan saham atau pengalihan penyertaan modal pada perusahaan pasangannya yang diterima oleh perusahaan modal ventura, d) penghasilan dari transaksi pengalihan harta berupa tanah dan/atau bangunan, usaha jasa konstruksi, usaha real estate, dan persewaan tanah dan/atau bangunan, dan e) penghasilan tertentu lainnya, yang diatur dengan atau berdasarkan Peraturan Pemerintah; 2) Sehubungan dengan tindak lanjut Peraturan Pemerintah tentang penghasilan atas usaha jasa konstruksi yang dikenai pajak bersifat final adalah Peraturan Pemerintah Nomor 40 Tahun 2009 tentang Perubahan atas Peraturan Pemerintah Nomor 51 Tahun 2008 tentang Pajak Penghasilan atas Penghasilan dari Usaha Jasa Konstruksi. Kemudian Pasal 9 Peraturan Pemerintah Nomor 40 Tahun 2009, diatur bahwa ketentuan lebih lanjut mengenai tata cara pemungutan, pemotongan, penyetoran, pelaporan, dan penatausahaan Pajak Penghasilan atas penghasilan dari usaha Jasa Konstruksi diatur dengan atau berdasarkan Peraturan Menteri Keuangan. (gambar 1); 3) Ketentuan pelaksanaan sebagaimana butir 2 adalah, Peraturan Menteri Keuangan Nomor 153/PMK.03/2009 tentang Perubahan atas Peraturan Menteri Keuangan Nomor 187/PMK.03/2008 tentang Tata Cara Pemotongan, Penyetoran, Pelaporan, dan Penatausahaan Pajak Penghasilan atas Penghasilan dari Usaha Jasa Konstruksi. Berikut ini bagan ketentuan kegiatan usaha jasa konstruksi menurut undang-undang pajak penghasilan.

\section{METODOLOGI PENELITIAN}

\section{Pendekatan Penelitian}

Pendekatan penelitian yang digunakan adalah penelitian kualitatif dengan teknik analisis data content analysis (analisis isi) dan hermeneutic analyisis (analisis hermeneutika). Ada sembilan jenis analisis Pendekaan kualitatif adalah: (1) narrative analysis, (2) semiotic, (3) content analysis, (4) conversation analysis, (5) discourse analysis, (6) grounded theory, (7) 


\section{Bagan Konstruksi Undang-Undang Minyak dan Gas}

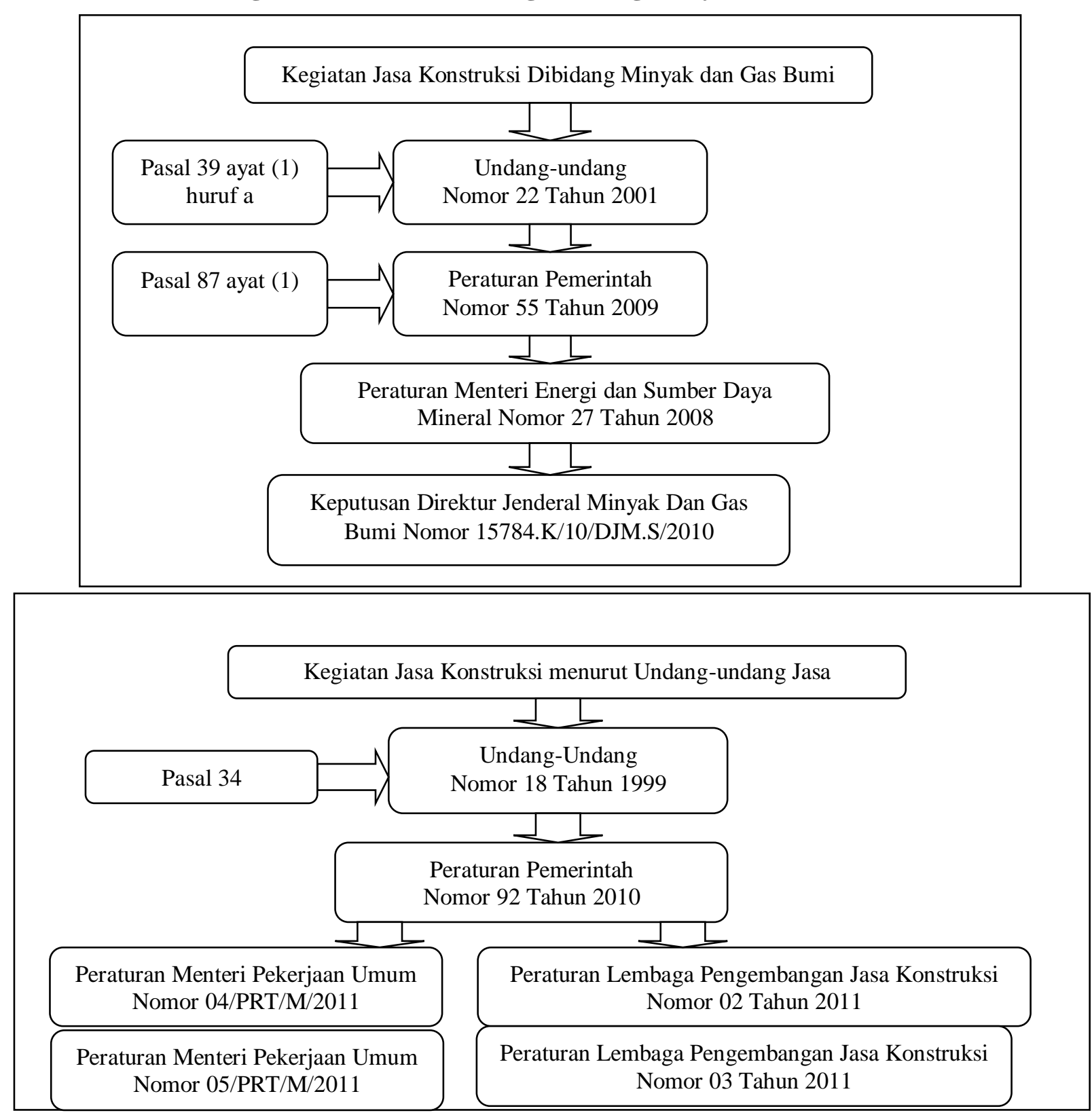

\section{Gambar 1}

hermeneutic, (8) phenomenology/heuristic analysis, dan (9) literary analysis (Tim Penyusun STIAMI, 2012: 56). Jenis analisis penelitian kualitatif yang menonjol digunakan dalam penelitian ilmu sosial (Bungin (Ed), 2006: 34) adalah: (1) Studi Fenomologi, (2) Studi Obervasi Partisipatif - Interaksionisme Simbolik, (3) Studi Etnometodologi, (4) Studi Etnografi, (5) Studi untuk menemukan Teori Grounded atau lazim dikenal dengan sebutan Penelitian Grounded, (6) Studi Life History, (7) Studi Hermeneutika, (8) Studi Analisis Isi atau Content Analysis, dan (9) Studi Kasus. (Gambar 2).
Dalam melakukan penelitian kualitatif, peneliti dapat memilih dan/atau menggabungkan satu atau lebih jenis analisis yang relevan dengan tema dan topik penelitian ilmu administrasi (Tim Penyusun STIAMI, 2012: 56).

Pola penelitian kualitatif menggunakan pendekatan empiris-rasional dan berpikir induktif (Santoso, 2005: 10). Penelitian kualitatif menekankan pelaksanaan observasi (pengamatan) yaitu, perubahan dari waktu ke waktu. Pola berpikir induktif adalah penarikan kesimpulan untuk hal spesifik dari gejala umum 


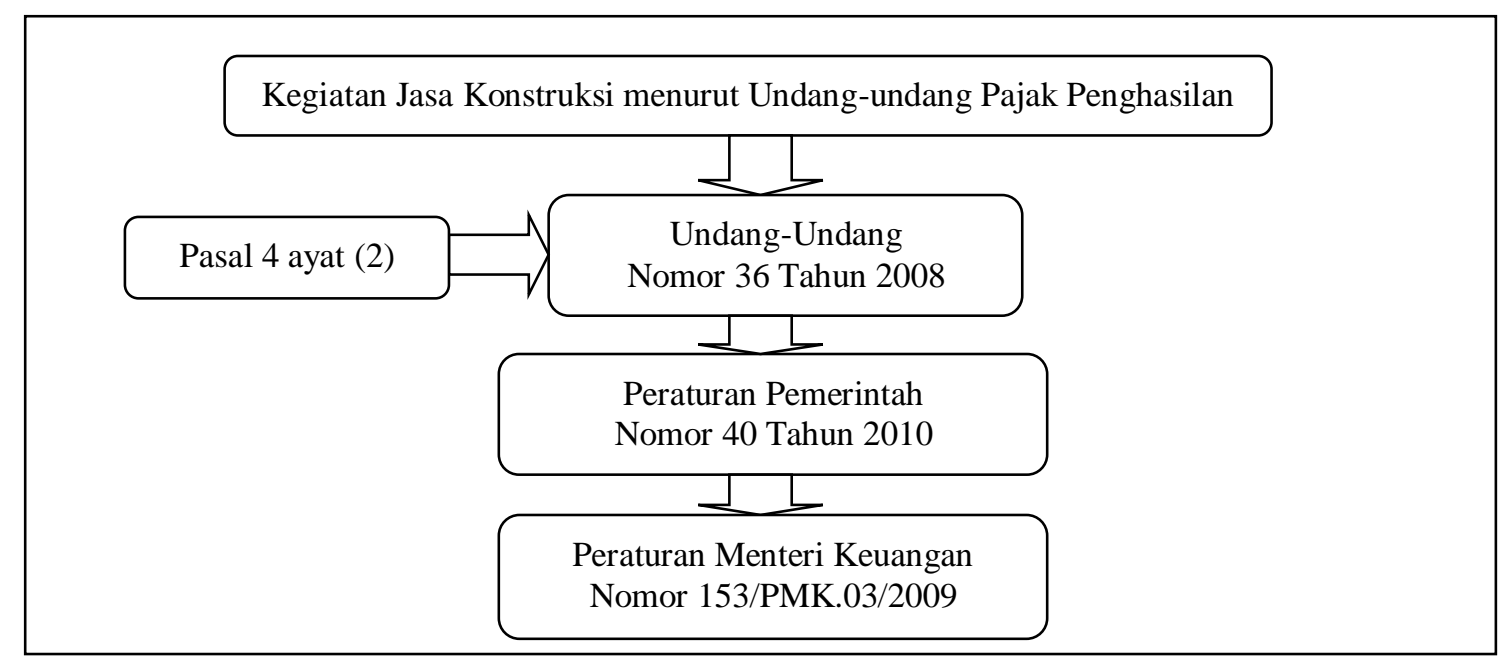

\section{Gambar 2}

(Kuncoro, 2003: 4). Penelitian kualitatif dapat dinyatakan sebagai kegiatan terencana yang mencakup separangkat praktek penafsiran yang memungkinkan dunia responden dan informan dapat dilihat menurut Agusta (Denzin dan Lincoln, 2000).

\section{Dimensi Penelitian}

Dimensi penelitian kualitatif meliputi penelitian deskriptif, serta penelitian kasus dan penelitian lapangan. Dimensi tujuan penjelasan bersifat diskriptif karena kajian terhadap data penelitian lapangan akan disajikan secara redaksional serta menggambarkan kategorikategori yang terkait dengan isu koordinasi pada objek penelitian (Tim Penyusun STIAMI, 2012: 49). Dimensi waktu terbagi dalam tiga dimensi penelitian, yakni yang pertama adalah cross-sectional, yang kedua adalah longtidunal yang terdiri dari panel, time series dan cohort analysis serta yang ketiga adalah case study (Tim Penyusun STIAMI, 2012: 49). Dimensi pertama dan kedua diterapkan untuk penelitian dengan pendekatan kuantitatif, sedangkan dimensi ketiga yakni studi kasus untuk pendekatan kualitatif (Tim Penyusun STIAMI, 2012: 49). Dimensi pengamatan yang berhubungan dengan data kualitatif dilakukan melalui pelaksanaan field research dan comparative historical (Tim Penyusun STIAMI, 2012: 49).
Penelitian deskriptif menurut Kuncoro (Boyd et al, 1989: 129) merupakan upaya untuk memperoleh deskripsi yang lengkap dan akurat dari suatu situasi. Penelitian kasus dan penelitian lapangan untuk mempelajari secara intensif tentang latar belakang keadaan sekarang dan interaksi lingkungan suatu unit sosial seperti individu, kelompok dan masyarakat (Suryana, 2010). Penelitian tersebut bersifat mendalam tentang suatu unit sosial tertentu yang hasilnya merupakan gambaran yang lengkap dan terorganisir (Suryana, 2010).

\section{Metode Analisis Data}

Analisis isi kualitatif yang aliran filososinya antipositivistik, menggunakan pendekatan interpretatif, atau sering dikenal dengan strukturalisme dan semiologi (McQuail, 2000: 327). Pendekatan interpretatif dilakukan terhadap peraturan perundang-undangan yang berlaku yang sistematik dan terstruktur. Peraturan tersebut digunakan oleh pelaku bisnis jasa penunjang minyak dan gas bumi di bidang jasa konstruksi. Menurut Budd (1967: 2) metode analisis isi pada dasarnya merupakan suatu teknik sistematik untuk menganalisis isi pesan dan mengolah pesan, atau suatu alat untuk mengobservasi dan menganalisis isi perilaku komunikasi yang terbuka dari komunikator yang dipilih. Analisis isi juga didefinisikan sebagai suatu metode untuk mempelajari dan menganalisis komunikasi 
secara sistematik, objektif, dan kuantitatif terhadap pesan yang tampak (Wimmer \& Dominick, 2000: 135).

Upaya pendekatan interpretif bertujuan untuk memperoleh pemahaman atas teks peraturan perundang-undangan yang berlaku. Menurut Riduwan (2012) upaya penginterpretasian teks untuk memperoleh pemahaman peraturan perundang-undangan yang berlaku disebut oleh Schmidt (2007: 272) sebagai hermeneutika (hermeneutics). Kata hermeneutika secara etimologis berasal dari bahasa Yunani hermeneuein, yang berarti penafsiran atau interpretasi (Nasirwan, 2011). Istilah tersebut dicetuskan oleh tokoh metologis Harmes seorang utusan dari langit yang menyampaikan pesan Jupiter kepada manusia (Sumaryono, 1999). Hermeneutika berhubungan dengan bahasa dan bahasa sangat penting keberadaannya dalam kehidupan manusia. Peranan hermeneutika cukup luas pada ilmu-ilmu kemanusiaan, seperti bidang sejarah, hukum, agama, filsafat, seni, kesusastraan, maupun linguistic atau semua ilmu (Sumaryono, 1999).

\section{Lokasi dan Pengumpulan Data Penelitian}

Lokasi penelitian dilakukan di KPP Minyak dan Gas Bumi periode April s.d. Juni 2012. Penulis terlibat langsung dalam pengamatan lapangan di KPP Minyak dan Gas Bumi karena penulis adalah salah satu pegawai KPP Minyak dan Gas Bumi sebagai Account Representative. Salah satu tugas Account Representative adalah memberikan pelayanan, bimbingan teknis dan pengawasan perpajakan terhadap Wajib Pajak. Penulis memberikan pelayanan dan bimbingan teknis, serta melakukan pengawasan perpajakan Wajib Pajak Minyak dan Gas Bumi, dan Wajib Pajak Penunjang Minyak dan Gas Bumi (seperti Kontraktor).

Pengumpulan data penelitian dilakukan melalui pengamatan dan didokumenkan dalam bentuk catatan-catatan. Selain itu, pengumpulan data penelitian dilakukan melalui studi pustaka seperti peraturan perpajakan, buku, jurnal, makalah, dan website.

\section{PEMBAHASAN}

\section{Kegiatan Usaha Jasa Konstruksi sebagai Kegiatan Usaha Penunjang Minyak dan Gas Bumi}

\section{Gambaran Umum}

Industri minyak dan gas bumi meliputi dua kegiatan usaha yaitu, kegiatan usaha inti dan kegiatan usaha penunjang minyak dan gas bumi. Kegiatan usaha inti meliputi kegiatan usaha hulu dan kegiatan usaha hilir. Kegiatan usaha hulu adalah kegiatan usaha yang berintikan atau bertumpu pada kegiatan usaha eksplorasi dan eksploitasi, sedangkan kegiatan usaha hilir adalah kegiatan usaha yang berintikan atau bertumpu pada kegiatan usaha Pengolahan, Pengangkutan, Penyimpanan, dan/atau Niaga.

Kegiatan usaha jasa penunjang minyak dan gas bumi adalah kegiatan usaha jasa layanan dalam kegiatan usaha hulu yang meliputi eksplorasi dan eksploitasi/produksi dan kegiatan usaha hilir yang meliputi pengolahan, pengangkutan, penyimpanan dan niaga. Kegiatan usaha jasa penunjang minyak dan gas bumi meliputi: (1) Usaha Jasa Konstruksi Minyak dan Gas Bumi adalah kegiatan usaha jasa layanan untuk penanganan pekerjaan bangunan atau konstruksi atau wujud fisik lainnya dalam menunjang kegiatan usaha minyak dan gas bumi. Bidang usaha ini terdiri atas: (a) Usaha Jasa Perencanaan Konstruksi termasuk rancang bangun dan rekayasa (design engineering); (b) Usaha Jasa Pelaksanaan Konstruksi termasuk E.ngineering, Procurement, and Construction (EPC), usaha instalasi, dan komisioning; dan (c) Usaha Jasa Pengawasan Konstruksi, yang pelaksanaannya dilakukan sesuai ketentuan peraturan perundang-undangan di bidang jasa konstruksi; (2) Usaha Jasa Non-Konstruksi Minyak dan Gas Bumi adalah kegiatan usaha jasa layanan pekerjaan dalam menunjang kegiatan usaha minyak dan gas bumi selain usaha jasa konstruksi minyak dan gas bumi dan usaha industri penunjang minyak dan gas bumi. Bidang usaha ini terdiri atas: (a) survei seismik; (b) survei non seismik; (c) geologi dan geofisika; (d) pemboran; (e) operasi sumur pemboran; (f) pekerjaan bawah air; (g) 
Bagan Industri Minyak dan Gas

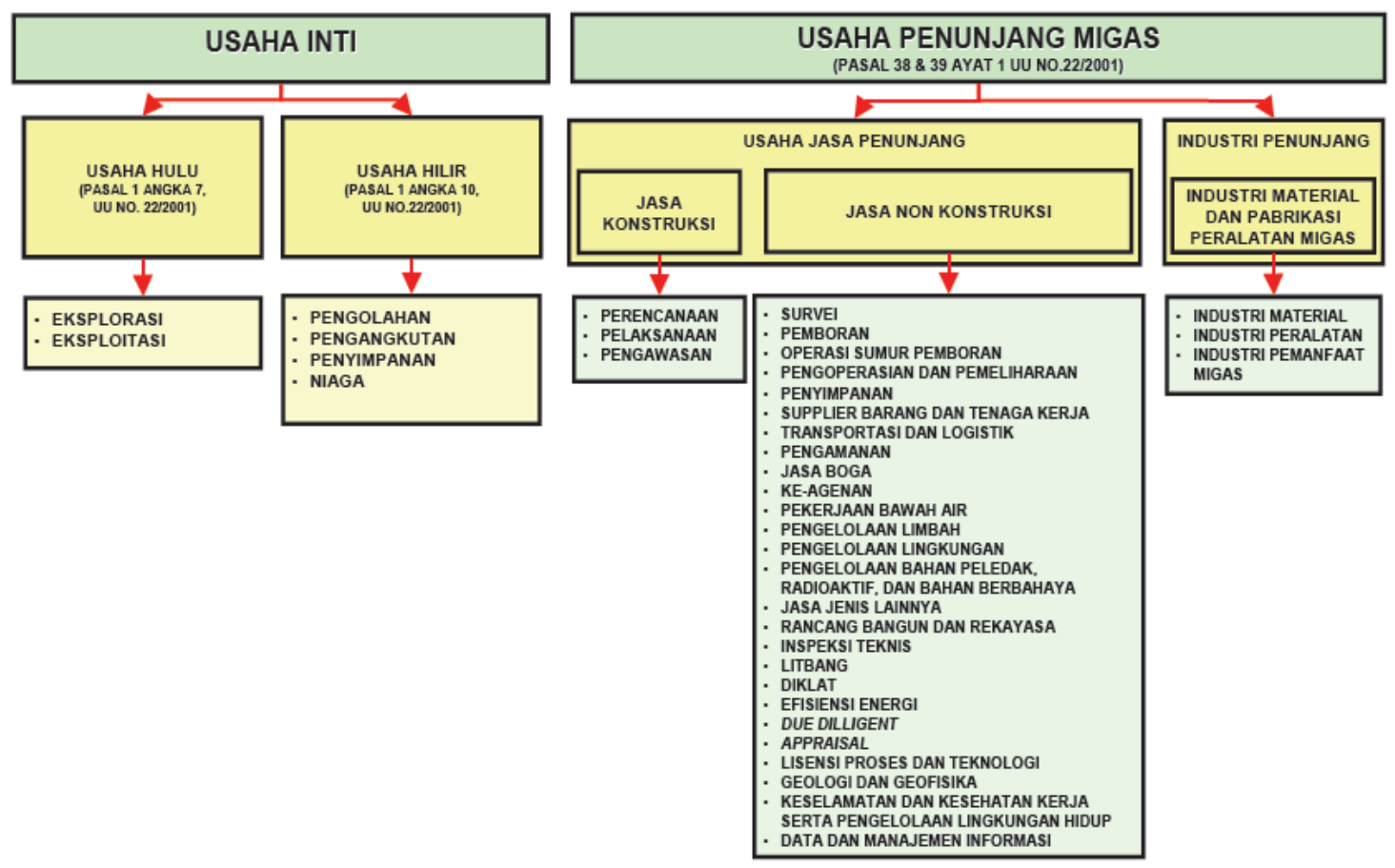

Gambar 3

pengelolaan bahan peledak, radio aktif, dan bahan berbahaya; (h) pangkalan logistik (shoreloffshore base); (i) pengoperasian dan pemeliharaan; (j) inspeksi teknis; (k) pengujian teknis; (l) pekerjaan paska operasi (decommisioning); (m) penelitian dan pengembangan; (n) pendidikan dan pelatihan; (o) pengelolaan Iimbah pemboran dan produksi; dan/atau (p) jasa lainnya; (3) Usaha Industri Penunjang Minyak dan Gas Bumi adalah kegiatan usaha industri yang menghasilkan barang, material dan/atau peralatan yang digunakan terkait sebagai penunjang langsung dalam kegiatai usaha Minyak dan Gas Bumi. Bidang usaha ini terdiri atas: (a) industri material; (b) industri peralatan (equipment); dan (c) industri pemanfaat Minyak dan Gas Bumi.

Bagan berikut ini menggambarkan industri minyak dan gas bumi secara keseluruhan sesuai dengan ketentuan yang berlaku. (Gambar 3).

\section{Surat Keterangan Terdaftar}

Surat Keterangan Terdaftar (SKT) kegiatan usaha penunjang minyak dan gas bumi adalah surat yang diberikan kepada perusahaan atau perseorangan yang melaksanakan usaha penunjang minyak dan gas bumi berdasarkan klasifikasi usaha penunjang sesuai dengan kompetensi yang dimiliki. Apabila Perusahaan dan perseorangan akan melaksanakan kegiatan usaha penunjang minyak dan gas bumi, maka diwajibkan memiliki Surat Keterangan Terdaftar (SKT). Namun, Kewajiban memiliki Surat Keterangan Terdaftar dikecualikan bagi industri pemanfaat minyak dan gas bumi. Perusahaan yang dapat melaksanakan kegiatan usaha penunjang minyak dan gas bumi meliputi: (a) Perusahaan Usaha Penunjang Minyak dan Gas Bumi Nasional; (b) Perusahaan Usaha Penunjang Minyak dan Gas Bumi Dalam Negeri; dan (c) Perusahaan Usaha Penunjang Minyak dan Gas Bumi Transnasional/Multinasional. Sedangkan Perseorangan yang dapat melaksanakan kegiatan usaha penunjang minyak dan gas bumi meliputi CV, Firma dan Perseorangan yang mempunyai keahlian untuk memberikan pelayanan usaha jasa konsultasi non konstruksi minyak dan gas bumi.

Formulir Surat Keterangan Terdaftar atas kegiatan usaha penunjang minyak dan gas bumi memuat sekurang-kurangnya: (a) Nomor dan tanggal penerbitan Surat Keterangan Terdaftar, (b) Nomor dan tanggal surat permohonan Surat 
Keterangan Terdaftar dari perusahaan atau perseorangan, (c) Dasar hukum penerbitan Surat Keterangan Terdaftar, (d) Nama perusahaan atau perseorangan, (e) Alamat perusahaan atau persorangan, (f) Klasifikasi perusahaan atau perseorangan, (g) Kewajiban perusahaan atau persorangan, (h) Sanksi administrasi, (i) Masa berlaku surat Keterangan Terdaftar.

Proses penerbitan Surat Keterangan Terdaftar atas kegiatan usaha penunjang minyak dan gas bumi adalah sebagai berikut: (1) Perusahaan atau perseorangan mengajukan permohonan kepada Direktur Teknik dan Lingkungan Minyak dan Gas Bumi dengan melampirkan Data Perusahaan atau Data Perseorangan; (2) Direktur Teknik dan Lingkungan Minyak dan Gas Bumi, melalui Subdirektorat Usaha Penunjang Minyak dan Gas Bumi meneliti dan mengevaluasi permohonan dan data yang disampaikan oleh perusahaan atau perseorangan; (3) Peneliti dan evaluasi permohonan sebagaimana dimaksud pada huruf b mencakup: (a) Kelengkapan surat permohonan dan lampirannya; (b) Kesesuaian data fotokopi dengan data yang asli; (c) Keabsahan dan kebenaran data sesuai peraturan perundang-undangan; (d) Klasifikasi bidang usaha perusahaan atau persorangan; (4) alam hal hasil penelitian dan evaluasi permohonan tidak lengkap dan/atau tidak benar, Subdirektorat Usaha Penunjang Minyak dan Gas Bumi menyampaikan hasil penelitian dan evaluasi permohonan, serta konsep surat penolakan kepada Direktur Teknik dan Lingkungan Minyak dan Gas Bumi; (5) Dalam jangka waktu paling lama lima hari kerja sejak disampaikan hasil penelitian dan evaluasi permohonan, serta konsep surat penolakana sebagimana dimaksud pada huruf d, Direktur Teknik dan Lingkungan Minyak dan Gas Bumi menerbitkan surat penolakan kepada pemohon; (6) Dalam hal hasil penelitian dan evaluasi permohonan telah lengkap dan/atau benar, Subdirektorat Usaha Penunjang Minyak dan Gas Bumi menyampaikan hasil penerlitian dan evaluasi permohonan yang telah lengkap dan benar kepada Direktur Teknik dan Lingkungan Minyak dan Gas Bumi; (7) Dalam jangka waktu paling lama lima hari kerja sejak disampaikan hasil penelitian dan evaluasi permohonan oleh Subdierktorat Usaha Penunjang Minyak dan Gas Bumi sebagaimana dimaksud pada huruf f, Direktur Teknik dan Lingkungan Minyak dan Gas Bumi menerbitkan Surat Keterangan Terdaftar.

Bagan berikut ini menggambarkan diagram alur proses penerbitan Surat Keterangan Terdaftar (SKT) sesuai dengan ketentuan yang berlaku.

\section{Kegiatan Usaha Jasa Konstruksi}

\section{Gambaran Umum}

Jasa konstruksi adalah layanan jasa konsultansi perencanaan pekerjaan konstruksi, layanan jasa pelaksanaan pekerjaan konstruksi, dan layanan jasa konsultansi pengawasan atas keseluruhan atau sebagian rangkaian kegiatan perencanaan dan/atau pelaksanaan beserta pengawasan yang mencakup pekerjaan arsitektural, sipil, mekanikal, elektrikal, dan tata lingkungan masing-masing beserta kelengkapannya untuk mewujudkan suatu bangunan atau bentuk fisik lain. Pihak-pihak yang terlibat dalam kegiatan usaha jasa konstruksi adalah: a) pengguna jasa merupakan orang perseorangan atau badan sebagai pemberi tugas atau pemilik pekerjaan/proyek yang memerlukan layanan jasa konstruksi; dan b. penyedia jasa merupakan orang perseorangan atau badan,yang kegiatan usahanya menyediakan layanan jasa konstruksi.

Perencana konstruksi, pelaksana konstruksi, dan pengawas konstruksi harus melakukan registrasi terlebih dahulu. Registrasi adalah suatu kegiatan untuk menentukan kompetensi profesi keahlian dan keterampilan tertentu, orang perseorangan dan badan; usaha untuk menentukan izin usaha sesuai klasifikasi dan kualifikasi yang diwujudkan dalam sertifikat.

\section{Registrasi Usaha Jasa Pelaksana Konstruksi}

Registrasi usaha jasa pelaksana konstruksi dilakukan oleh Lembaga Pengembangan Jasa Konstruksi (LPJK). Registrasi tersebut menghasilkan dua hal, yaitu: (a) Tanda Daftar Usaha Orang Perseorangan (TDUP) adalah sertifikat tanda bukti pengakuan formal atas tingkat/kedalaman kompentensi dan kemampuan usaha jasa pelaksana konstruksi 
orang perseorangan dengan ketetapan klasifikasi dan kualifikasi usaha; (b) Sertifikat Badan Usaha (SBU) adalah sertifikat tanda bukti pengakuan formal atas tingkat/kedalaman kompetensi dan kemampuan usaha dengan ketetapan klasifikasi dan kualifikasi Badan Usaha.

Bentuk usaha jasa pelaksana konstruksi meliputi usaha orang perseorangan, serta badan usaha nasional dan badan usaha asing. Setiap usaha orang perseorangan yang melakukan usaha jasa pelaksana konstruksi harus memiliki Tanda Daftar Usaha Orang Perseorangan (TDUP), sedangkan setiap badan usaha baik nasional dan asing yang melakukan usaha jasa pelaksana konstruksi harus memiliki Sertifikat Badan Usaha (SBU).

Penggolongan kualifikasi usaha jasa pelaksana konstruksi didasarkan pada kriteria tingkat/kedalaman kompetensi dan potensi kemampuan usaha, yang selanjutnya dibagi menurut kemampuan melaksanakan pekerjaan berdasarkan kriteria risiko, dan/atau kriteria penggunaan teknologi, dan/atau kriteria besaran biaya, dapat dibagi jenjang kompetensinya dalam Gred sebagai berikut: (1) Kualifikasi usaha besar (usaha non kecil) berupa: (a) Gred 7, (b) Gred 6, dan (c) Gred 5; (2) kualifikasi usaha kecil, berupa: (a) Gred 4, (b) Gred 3, (c) Gred 2, dan (d) Gred 1 (usaha orang perseorangan)

\section{Registrasi Usaha Jasa Perencana dan Pengawas Konstruksi}

Registrasi usaha jasa perencana dan pengawas konstruksi dilakukan oleh Lembaga Pengembangan Jasa Konstruksi (LPJK). Registrasi tersebut menghasilkan dua hal, yaitu: (a). Tanda Daftar Usaha Orang Perseorangan (TDUP) adalah sertifikat tanda bukti pengakuan formal atas tingkat/kedalaman kompentensi dan kemampuan usaha jasa perencana dan pengawas konstruksi orang perseorangan dengan ketetapan klasifikasi dan kualifikasi usaha; (b) Sertifikat Badan Usaha (SBU) adalah sertifikat tanda bukti pengakuan formal atas tingkat/kedalaman kompetensi kemampuan usaha dengan ketetapan klasifikasi dan kualifikasi Badan Usaha.
Bentuk usaha jasa perencana konstruksi dan jasa pengawas konstruksi meliputi usaha orang perseorangan; dan badan usaha nasional dan badan usaha asing. Setiap usaha orang perseorangan yang melakukan usaha jasa perencana konstruksi dan jasa pengawas konstruksi harus memiliki Tanda Daftar Usaha Orang Perseorangan (TDUP), sedangkan setiap badan usaha yang melakukan usaha jasa perencana konstruksi dan jasa pengawas konstruksi memiliki Sertifikat Badan Usaha (SBU).

Penggolongan kualifikasi usaha jasa perencana konstruksi dan usaha jasa pengawas konstruksi didasarkan pada kriteria tingkat/kedalaman kompetensi dan potensi kemampuan usaha, serta kemampuan melakukan perencanaan dan pengawasan pekerjaan berdasarkan kriteria risiko dan/atau kriteria penggunaan teknologi dan/atau kriteria besaran biaya. Penggolongan kualifikasi usaha jasa perencana konstruksi dan jasa pengawas konstruksi tersebut, jenjang kompetensinya dalam Gred, dapat dibagi dalam golongan: (1) kualifikasi usaha besar (usaha non kecil) berupa Gred 4; (2) kualifikasi usaha kecil (usaha kecil), berupa: (a) Gred 3, (b) Gred 2, dan (c) Gred 1 (usaha orang perseorangan).

\section{Izin Usaha Konstruksi Nasional}

Pemberian izin usaha jasa konstruksi nasional diberikan kepada Badan Usaha Jasa Konstruksi (BUJK), adalah badan usaha yang berbentuk badan hukum, yang kegiatan usahanya bergerak di bidang jasa konstruksi. Izin tersebut diberikan oleh Pemerintah Kabupaten/Kota dan didasarkan oleh sertifikat, sebagai: (a) tanda bukti pengakuan penetapan klasifikasi dan kualifikasi atas kompetensi dan kemampuan usaha di bidang jasa konstruksi baik yang berbentuk orang perseorangan atau badan usaha; (b) tanda bukti pengakuan atas kompetensi dan kemampuan profesi keterampilan kerja dan keahlian kerja orang perseorangan di bidang jasa konstruksi menurut disiplin keilmuan dan/atau keterampilan dan tertentu dan/atau kefungsian dan/atau keahlian tertentu.

Izin Usaha Jasa Konstruksi diberikan oleh Pemerintah Kabupaten/Kota tempat BUJK 


\section{DIAGRAM PROSES PENERBITAN SURAT KETERANGAN TERDAFTAR}

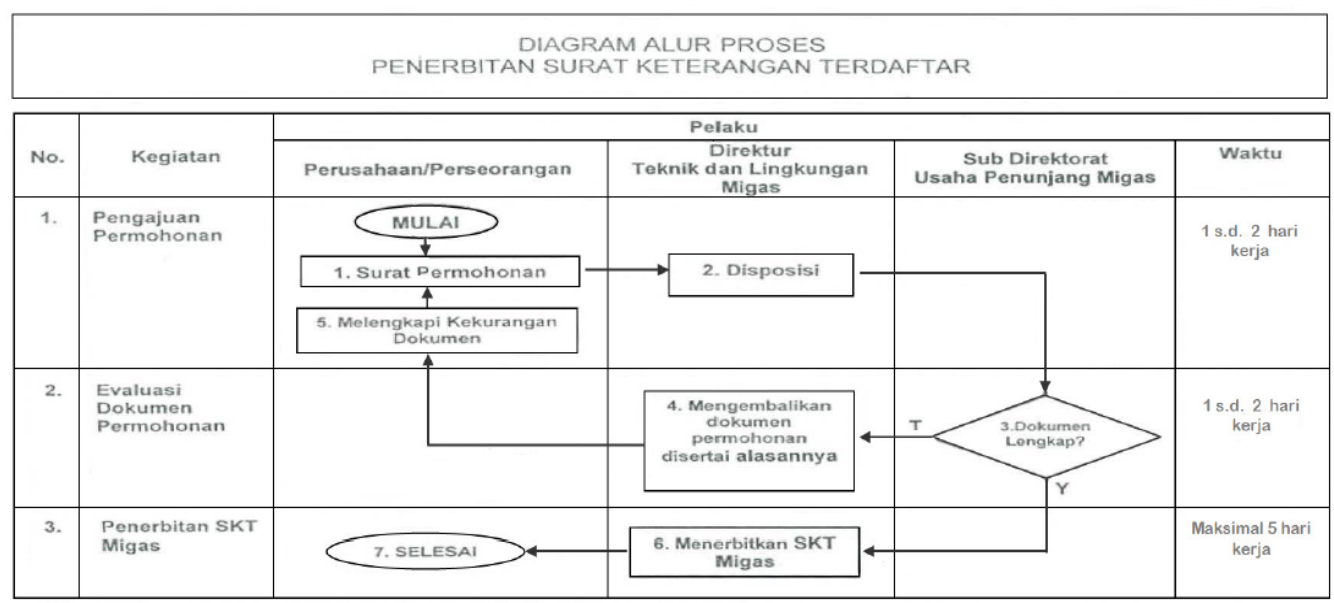

Batas Nilai Satu Perkejaan Kualifikasi Usaha Jasa Pelaksana Konstruksi

\begin{tabular}{llcl}
\hline No. & Golongan Usaha & Kualifikasi & \multicolumn{1}{c}{ Batas Nilai satu Perkejaan (Rp.) } \\
\hline 1. & Perorangan & Gred 1 & 0 s.d. $50.000 .000,00$ \\
\hline 2. & Kecil & Gred 2 & 0 s.d. $300.000 .000,00$ \\
\cline { 2 - 3 } & & Gred 3 & 0 s.d. $600.000 .000,00$ \\
\cline { 2 - 3 } & & Gred 4 & 0 s.d. $1.000 .000 .000,00$ \\
\hline 3. & Besar & Gred 5 & $>1.000 .000 .000,00$ s.d. $10.000 .000 .000,00$ \\
\cline { 2 - 3 } & & Gred 6 & $>1.000 .000 .000,00$ s.d. $25.000 .000 .000,00$ \\
\hline
\end{tabular}

\section{Batas Nilai Satu Perkejaan Kualifikasi Usaha Jasa Perencana Konstruksi Dan} Usaha Jasa Pengawas Konstruksi

\begin{tabular}{llll}
\hline No. & Golongan Usaha & Kualifikasi & Batas Nilai satu Perkejaan (Rp.) \\
\hline 1. & Perorangan & Gred 1 & 0 s.d. $50.000 .000,00$ \\
\hline 2. & Kecil & Gred 2 & 0 s.d. $400.000 .000,00$ \\
\cline { 2 - 3 } & & Gred 3 & $>400.000 .000,00$ s.d. $1.000 .000 .000,00$ \\
\hline 3. & Besar & Gred 4 & $>400.000 .000,00$ s.d. tidak terbatas
\end{tabular}

tersebut berdomisili. Bupati/Walikota dapat menunjuk Unit Kerja/Instansi untuk memberikan IUJK dalam rangka pelaksanaan pemberian IUJK. Dalam hal pemberian IUJK dilaksanakan oleh unit kerja/instansi yang tidak membidangi jasa konstruksi, IUJK dapat diberikan setelah mendapatkan rekomendasi dari unit kerja/instansi yang membidangi jasa konstruksi.
Persyaratan permohonan izin usaha jasa konstruksi nasional yang diberikan oleh Pemerintah Kabupaten/Kota meliputi: (a) mengisi Formulir Permohonan; (b) menyerahkan rekaman Akta Pendirian BUJK; (c) menyerahkan rekaman Sertifikat Badan Usaha (SBU) yang telah diregistrasi oleh Lembaga; (d) menyerahkan rekaman Sertifikat Keahlian (SKA) dan/atau Sertifikat Keterampilan (SKT) dari Penanggung Jawab 
Teknik Badan Usaha (PJT-BU) yang telah diregistrasi oleh Lembaga; (e) menyerahkan rekaman Kartu Penanggung Jawab Teknik Badan Usaha (PJT-BU) yang dilengkapi surat pernyataan pengikatan diri Tenaga Ahli/Terampil dengan Penanggung Jawab Utama Badan Usaha (PJU-BU).

Usaha orang perseorangan wajib memiliki SKA/SKT dan terdaftar pada unit kerja/instansi pemberi IUJK. Usaha orang perseorangan tersebut diberikan Kartu Tanda Daftar.

\section{Izin Perwakilan Badan Usaha Jasa Konstruksi Asing}

Pemberian izin perwakilan badan usaha jasa konstruksi asing diberikan kepada Badan Usaha Jasa Konstruksi Asing (BUJKA), yaitu badan usaha yang didirikan menurut hukum dan berdomisili di negara asing, memiliki kantor perwakilan di Indonesia, dan dipersamakan dengan badan hukum Perseroan Terbatas yang bergerak di bidang usaha jasa konstruksi. Izin tersebut diberikan oleh Pemerintah kepada BUJKA dan didasarkan sertifikat, sebagai: a) tanda bukti pengakuan penetapan klasifikasi dan kualifikasi atas kompetensi dan kemampuan usaha di bidang jasa konstruksi baik yang berbentuk orang perseorangan atau badan usaha; atau b) tanda bukti pengakuan atas kompetensi dan kemampuan profesi keterampilan kerja dan keahlian kerja orang perseorangan di bidang jasa konstruksi menurut disiplin keilmuan dan/atau keterampilan tertentu dan/atau kefungsian dan/atau keahlian tertentu.

Izin Perwakilan diberikan oleh Menteri atau Pejabat yang ditunjuk atas nama Menteri kepada BUJKA. Izin Perwakilan hanya diberikan kepada BUJKA yang memiliki kualifikasi besar. Izin Perwakilan tersebut dapat diberikan setelah BUJKA mendapatkan penyetaraan klasifikasi dan kualifikasi yang dinyatakan dalam bentuk sertifikat dari Lembaga. Badan Usaha Jasa Konstruksi Asing yang telah memiliki Izin Perwakilan tersebut, dapat melakukan kegiatan usaha jasa konstruksi di seluruh wilayah Indonesia.

Persyaratan permohonan izin perwakilan badan usaha jasa konstruksi asing yang diberikan oleh Menteri atau Pejabat yang ditunjuk atas nama Menteri sekurangkurangnya meliputi: (a) mengisi Formulir Permohonan; (b) menyerahkan rekaman Akta Pendirian BUJKA induk di negara asal yang telah dilegalisir; (c) menyerahkan data BUJKA atau company profile; (d) menyerahkan Surat Rekomendasi dari kedutaan besar negara asal di Indonesia yang menyatakan bahwa BUJKA yang bersangkutan merupakan badan usaha yang teregistrasi dengan sah dan memiliki reputasi baik; (e) menyerahkan rekaman Izin Usaha Jasa Konstruksi BUJKA induk yang masih berlaku; (f) menyerahkan rekaman bukti nilai kemampuan BUJKA induk yang masih berlaku; (g) menyerahkan Sertifikat BUJKA hasil penyetaraan kemampuan BUJKA dari Lembaga tingkat Nasional; (h) menyerahkan Surat Penunjukan Kepala Perwakilan BUJKA oleh BUJKA induk (Letter of Appointment); (i) menyerahkan Laporan Keuangan yang terbaru dari BUJKA induk; (j) menyerahkan rekaman Paspor atau Kartu Tanda penduduk (KTP) Kepala Perwakilan; (k) menyerahkan Daftar Riwayat Hidup Kepala Perwakilan BUJKA; (l) menyerahkan Surat Keterangan Domisili kantor perwakilan BUJKA di Indonesia yang diterbitkan oleh Kelurahan setempat.

\section{Pajak Penghasilan Pasal 4 ayat (2) yang Bersifat Final}

Prinsip aspek perpajakan terhadap kegiatan usaha jasa kontruksi baik menurut undangundang minyak dan gas bumi, serta undangundang jasa konstruksi adalah sama, yaitu objek penghasilan atas kegiatan usaha jasa konstruksi yang dikenakan Pajak Penghasilan yang bersifat final menurut undang-undang pajak penghasilan. Tarif Pajak Penghasilan untuk usaha Jasa Konstruksi adalah sebagai berikut: a) dua persen untuk Pelaksanaan Konstruksi yang dilakukan oleh Penyedia Jasa yang memiliki kualifikasi usaha kecil; b) empat persen untuk Pelaksanaan Konstruksi yang dilakukan oleh Penyedia Jasa yang tidak memiliki kualifikasi usaha; c) tiga persen untuk Pelaksanaan Konstruksi yang dilakukan oleh Penyedia Jasa selain Penyedia Jasa sebagaimana dimaksud dalam huruf a dan huruf b; d) empat persen untuk Perencanaan Konstruksi atau Pengawasan Konstruksi yang 


\section{Tabel 3. Skema Tarif dan Dasar Pengenaan PPh yang Bersifat Final untuk Jasa Konstruksi}

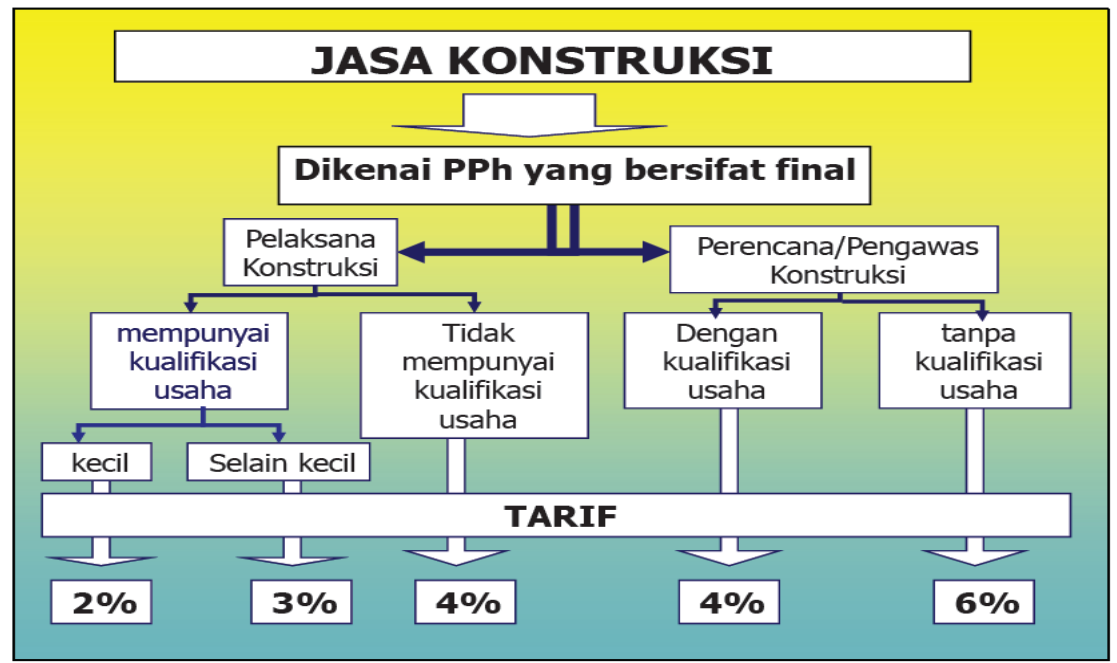

dilakukan oleh Penyedia Jasa yang memiliki kualifikasi usaha; dan e) enam persen untuk Perencanaan Konstruksi atau Pengawasan Konstruksi yang dilakukan oleh Penyedia Jasa yang tidak memiliki kualifikasi usaha. Menurut buku Oasis Pemotongan/Pemungutan (Direktorat Peraturan Perpajakan II, 2011: 14), skema tarif dan dasar pengenaan $\mathrm{PPh}$ yang bersifat final untuk Jasa Konstruksi dapat dilihat pada tabel 3.

Pelunasan Pajak Penghasilan yang bersifat final atas penghasilan dari usaha jasa konstruksi melalui cara: (1) dipotong oleh Pengguna Jasa pada saat pembayaran, dalam hal Pengguna Jasa merupakan pemotong pajak; (2) disetor sendiri oleh Penyedia Jasa, dalam hal Pengguna Jasa bukan merupakan pemotong pajak; (3) dalam hal: (a) pemotongan oleh Pengguna Jasa terdapat selisih kekurangan $\mathrm{PPh}$ yang terutang berdasarkan Nilai Kontrak Jasa Konstruksi dengan PPh berdasarkan pembayaran yang telah dipotong atau disetor sendiri, selisih kekurangan tersebut disetor sendiri oleh Penyedia Jasa; (b) nilai Kontrak Jasa Konstruksi tidak dibayar sepenuhnya oleh Pengguna Jasa, atas Nilai Kontrak Jasa Konstruksi yang tidak dibayar tersebut tidak terutang PPh yang bersifat final, dengan syarat Nilai Kontrak Jasa Konstruksi yang tidak dibayar tersebut dicatat sebagai piutang yang tidak dapat ditagih; (1) Piutang yang tidak dapat ditagih merupakan piutang yang nyatanyata tidak dapat ditagih; (2) Dalam hal piutang yang nyata-nyata tidak dapat ditagih dapat ditagih kembali, tetap dikenakan PPh yang bersifat final.

Batas waktu penyetoran PPh Pasal 4 ayat (2) atas kegiatan usaha jasa konstruksi adalah sebagai berikut: (1) PPh Pasal 4 ayat (2) yang dipotong oleh Pemotong Pajak Penghasilan harus disetor paling lama tanggal 10 bulan berikutnya setelah Masa Pajak berakhir kecuali ditetapkan lain oleh Menteri Keuangan; (2) PPh Pasal 4 ayat (2) yang harus dibayar sendiri oleh Wajib Pajak harus disetor paling lama tanggal 15 bulan berikutnya setelah Masa Pajak berakhir kecuali ditetapkan lain oleh Menteri Keuangan.

Dalam hal tanggal jatuh tempo pembayaran atau penyetoran pajak bertepatan dengan hari libur termasuk hari Sabtu atau hari libur nasional, pembayaran atau penyetoran pajak dapat dilakukan pada hari kerja berikutnya. Hari libur nasional tersebut termasuk hari yang diliburkan untuk penyelenggaraan Pemilihan Umum yang ditetapkan oleh Pemerintah dan cuti bersama secara nasional yang ditetapkan oleh Pemerintah.

Batas waktu pelaporan SPT Masa PPh Pasal 4 ayat (2) atas kegiatan usaha jasa konstruksi adalah Wajib Pajak orang pribadi atau badan, baik yang melakukan pembayaran pajak tersendiri maupun yang ditunjuk sebagai Pemotong $\mathrm{PPh}$ wajib menyampaikan Surat Pemberitahuan Masa paling lama dua puluh hari setelah Masa Pajak berakhir. Dalam hal 
Tabel 4. Penghitungan Pajak Penghasilan Pasal 26 ayat (4) bagi BUT

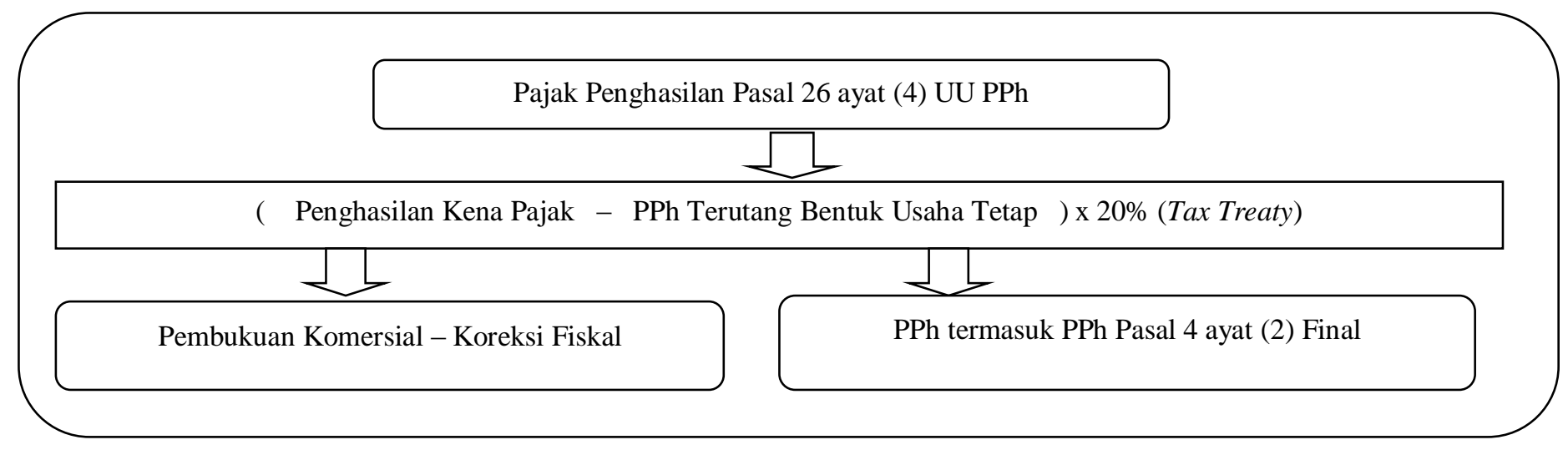

batas akhir pelaporan tersebut bertepatan dengan hari libur termasuk hari Sabtu atau hari libur nasional, pelaporan dapat dilakukan pada hari kerja berikutnya. Hari libur nasional tersebut termasuk hari yang diliburkan untuk penyelenggaraan Pemilihan Umum yang ditetapkan oleh Pemerintah dan cuti bersama secara nasional yang ditetapkan oleh Pemerintah.

\section{Pajak Penghasilan Pasal 26 ayat (4)}

Dalam hal Penyedia Jasa adalah Bentuk Usaha Tetap (BUT), tarif Pajak Penghasilan Pasal 4 ayat (2) Final tidak termasuk Pajak Penghasilan Pasal 26 ayat (4) Undang-Undang PPh. Dasar Pengenaan Pajak (DPP) Pasal 26 ayat (4) Undang-Undang PPh adalah Penghasilan Kena Pajak yang dihitung berdasarkan pembukuan yang sudah dikoreksi fiskal dikurangi dengan Pajak Penghasilan termasuk Pajak Penghasilan yang bersifat final (Gunadi, 2010: 111). Untuk memberikan gambaran yang jelas tentang sistematika penghitungan Pajak Penghasilan Pasal 26 ayat (4) bagi BUT yang memperoleh penghasilan yang dikenakan PPh yang bersifat final seperti PPh Pasal 4 ayat (2) atas Jasa Konstruksi dapat dilihat pada tabel 4.

Pajak Penghasilan Pasal 26 ayat (4) Undang-Undang $\mathrm{PPh}$ tidak dikenakan di Indonesia, apabila seluruh Penghasilan Kena Pajak sesudah dikurangi Pajak Penghasilan dari suatu Bentuk Usaha Tetap ditanamkan kembali di Indonesia dalam bentuk: (a) penyertaan modal pada perusahaan yang baru didirikan dan berkedudukan di Indonesia sebagai pendiri atau peserta pendiri; (b) penyertaan modal pada perusahaan yang sudah didirikan dan berkedudukan di Indonesia sebagai pemegang saham; (c) pembelian aktiva tetap yang digunakan oleh Bentuk Usaha Tetap untuk menjalankan usaha Bentuk Usaha Tetap atau melakukan kegiatan Bentuk Usaha Tetap di Indonesia; (d) investasi berupa aktiva tidak berwujud oleh Bentuk Usaha Tetap untuk menjalankan usaha Bentuk Usaha Tetap atau melakukan kegiatan Bentuk Usaha Tetap di Indonesia.

\section{Simpulan}

Berdasarkan pembahasan penelitian proses bisnis dan aspek perpajakan jasa penunjang minyak dan gas bumi untuk kegiatan jasa konstruksi dengan teknik analisis data content analysis dan hermeneutic analyisis, dengan ini dapat disimpulkan beberapa hal adalah sebagai berikut: (1) Kegiatan usaha jasa konstruksi menurut undang-undang jasa konstruksi merupakan kegiatan yang terkait dengan layanan jasa konsultansi perencanaan pekerjaan konstruksi, layanan jasa pelaksanaan pekerjaan konstruksi, dan layanan jasa konsultansi pengawasan atas keseluruhan atau sebagian rangkaian kegiatan perencanaan dan/atau pelaksanaan beserta pengawasan yang mencakup pekerjaan arsitektural, sipil, mekanikal, elektrikal, dan tata lingkungan masing-masing beserta kelengkapannya untuk mewujudkan suatu bangunan atau bentuk fisik lain. Setiap usaha orang perseorangan yang 


\section{Studi Kasus Penghitungan PPh Pasal 4 ayat (2) Bersifat Final dan PPh Pasal 26 ayat (4) Wajib Pajak Dalam Negeri (Perseroan Terbatas)}

PT Konstruksi Mega dengan NPWP 01.231.676.2-081.000 yang terdaftar di KPP Minyak dan Gas Bumi dan mempunyai data Laporan Laba (Rugi) tahun 2012 adalah sebagai berikut:

1. Penjualan Bersih

2. Harga Pokok Penjualan

3. Beban Operasional

4. Penghasilan Diluar Usaha

5. Beban Diluar Usaha

'6. Penyesuaian atau Koreksi Fiksal :
a. Beban Sumbangan
b. Beban Entertaintment
c. Selisih Lebih Penyusutan Fiskal
d. Selisih Kurang Penyusutan Fiskal
e. Beban Jamuan tanpa Daftar Nominatif
f. PPh Pasal 21 Ditanggung Perusahaan

$$
\begin{array}{r}
101,290,000,000 \\
69,890,100,000 \\
20,258,000,000 \\
2,025,800,000 \\
243,096,000
\end{array}
$$

$100,500,000$

$308,500,000$

$113,200,000 *)$

$\left.490,000,000^{* *}\right)$

$35,000,000$

$\left.760,000,000^{\star \star \star}\right)$

\section{Catatan :}

*) Penyusutan Komersial lebih kecil dengan Penyusutan Fiskal

${ }^{\star *}$ ) Penyusutan Komersial lebih besar dengan Penyusutan Fiskal

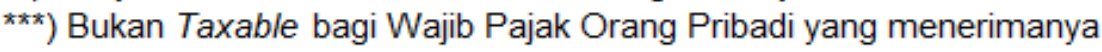

\section{Pertanyaan:}

1. Berapakah Pajak Penghasilan Pasal 4 ayat (2) tahun pajak 2012 yang dipotong oleh Pihak Ketiga? Asumsi Penjualan Bersih sama dengan Dasar Pengenaan Pajak (DPP) PPh Pasal 4 ayat (2) selama tahun pajak 2012.

2. Berapakah Pajak Penghasilan Badan tahun pajak 2012?

\section{Jawaban :}

1. DPP PPh Pasal 4 ayat (2) atas Jasa Konstruksi

Tarif Pelaksana Jasa Konstruksi (Kualifikasi Besar)

PPh Pasal 4 ayat (2)

$\begin{array}{r}101,290,000,000 \\ 3 \% \\ \hline 3,038,700,000 \\ \hline \hline\end{array}$

2. Penghitungan Pajak Penghasilan Badan tahun pajak 2012

1. Penjualan Bersih

2. Harga Pokok Penjualan

3. Beban Operasional

4. Penghasilan Diluar Usaha

5. Beban Diluar Usaha

6. Penghasilan Neto Komersial

8. Penghasilan Dikenakan PPh Final

9. Penghasilan Neto Fiskal

10. Kompensasi Kerugian Fiskal

11. Penghasilan Kena Pajak

12 Pajak Penghasilan Terutang

Jadi, Pajak Penghasilan Badan tahun pajak 2012

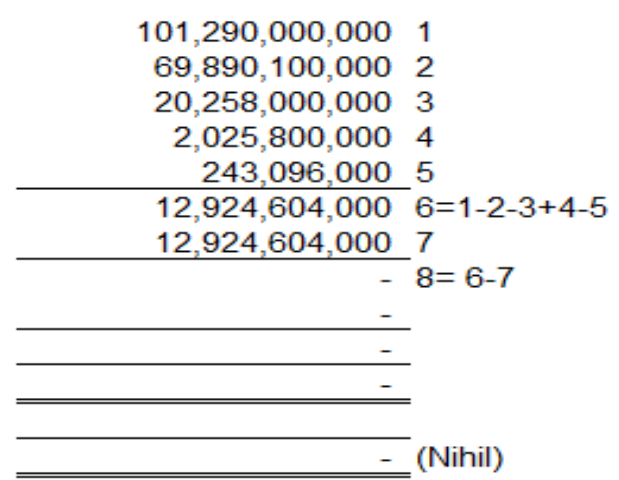

Catatan:

Penghitungan PPh Badan berdasarkan Peraturan Pemerintah Nomor 94 Tahun 2010 tentang Penghitungan Penghasilan Kena Pajak dan Pelunasan Pajak Penghasilan dalam Tahun Berjalan dan Peraturan Direktur Jenderal Pajak Nomor PER-26/PJ/2013 tentang Perubahan atas Peraturan Direktur Jenderal Pajak Nomor PER-34/PJ/2010 tentang Bentuk Formulir Surat Pemberitahuan Tahunan Pajak Penghasilan Wajib Pajak Orang Pribadi dan Wajib Pajak Badan Beserta Petunjuk Pengisiannya. 


\subsubsection{Wajib Pajak Luar Negeri (Bentuk Usaha Tetap)}

BUT BCDE, Ltd. dengan NPWP 01.111.433.2-081.000 yang terdaftar di KPP Minyak dan Gas Bumi dan mempunyai data Laporan Laba (Rugi) tahun 2012 adalah sebagai berikut:

1. Penjualan Bersih

2. Harga Pokok Penjualan

3. Beban Operasional

4. Penghasilan Diluar Usaha

5. Beban Diluar Usaha

'6. Penyesuaian atau Koreksi Fiksal :

a. Beban Sumbangan

b. Beban Entertaintment

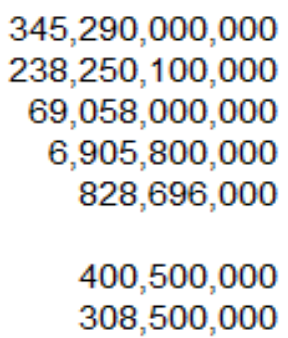

\section{Pertanyaan :}

1. Berapakah Pajak Penghasilan Pasal 4 ayat (2) tahun pajak 2012 yang dipotong oleh Pihak Ketiga? Asumsi Penjualan Bersih sama dengan Dasar Pengenaan Pajak (DPP) PPh Pasal 4 ayat (2) selama tahun pajak 2012.

2. Berapakah Pajak Penghasilan Badan tahun pajak 2012?

3. Berapakah PPh Pasal 26 ayat (4) tahun pajak 2012? (Asumsi BUT BCDE, Ltd. mengirimkan labanya ke kantor pusat di luar negeri)

\section{Jawaban :}

1. DPP PPh Pasal 4 ayat (2) atas Jasa Konstruksi Tarif Pelaksana Jasa Konstruksi (Kualifikasi Besar) PPh Pasal 4 ayat (2) Final

$345,290,000,000$

$3 \%$
$10,358,700,000$

'2. Penghitungan Pajak Penghasilan Badan tahun pajak 2012

\section{Penjualan Bersih}

2. Harga Pokok Penjualan

4. Penghasilan Diluar Usaha

5. Beban Diluar Usaha

6. Penghasilan Neto Komersial

8. Penghasilan Dikenakan PPh Final

9. Penghasilan Neto Fiskal

10. Kompensasi Kerugian Fiskal

12 Pajak Penghasilan Terutang

Jadi, Pajak Penghasilan Badan tahun pajak 2012

Catatan
3. Beban Operasional

11. Penghasilan Kena Pajak

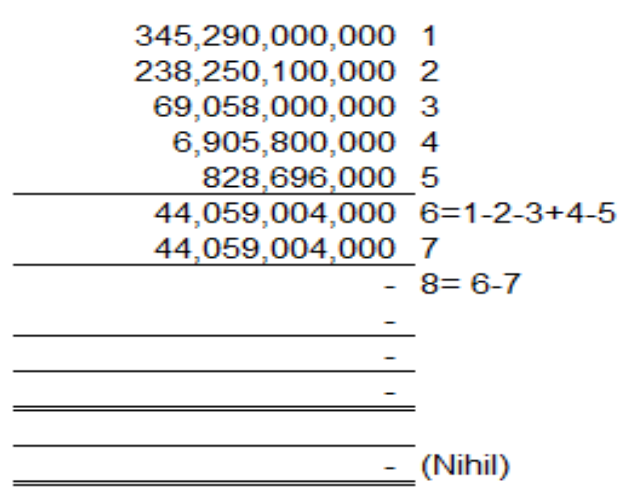

Penghitungan PPh Badan berdasarkan Peraturan Pemerintah Nomor 94 Tahun 2010 tentang Penghitungan Penghasilan Kena Pajak dan Pelunasan Pajak Penghasilan dalam Tahun Berjalan dan Peraturan Direktur Jenderal Pajak Nomor PER-26/PJ/2013 tentang Perubahan atas Peraturan Direktur Jenderal Pajak Nomor PER-34/PJ/2010 tentang Bentuk Formulir Surat Pemberitahuan Tahunan Pajak Penghasilan Wajib Pajak Orang Pribadi dan Wajib Pajak Badan Beserta Petunjuk Pengisiannya. 
PPh Pasal 26 ayat (4) tahun pajak 2012

1. Penghasilan Neto Komersial

Penyesuaian atau Koreksi Fiksal

a. Beban Sumbangan

b. Beban Entertaintment

Penghasilan Neto Fiskal

Kompensasi Kerugian Fiskal

Penghasilan Kena Pajak

Pajak Penghasilan Badan *)

DPP PPh Pasal 26 ayat (4)

Tarif PPh Pasal 26 ayat (4)

PPh Pasal 26 ayat (4)

Jadi, PPh Pasal 26 ayat (4) tahun pajak 2012

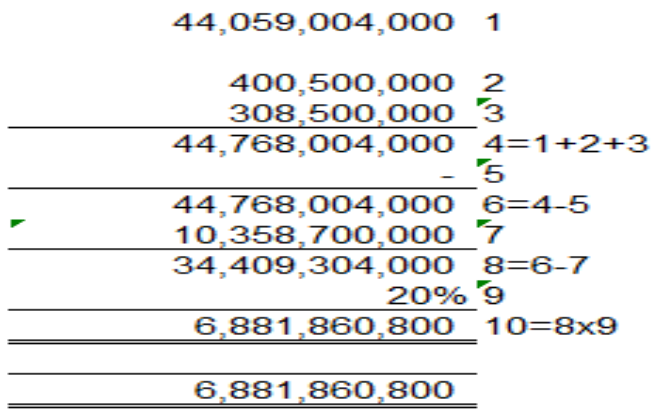

*) Pajak Penghasilan Badan = PPh Pasal 4 ayat (2) Final

Tabel 5. Skema Kegiatan Usaha Jasa Konstruksi Menurut Undang-Undang Jasa Konstruksi

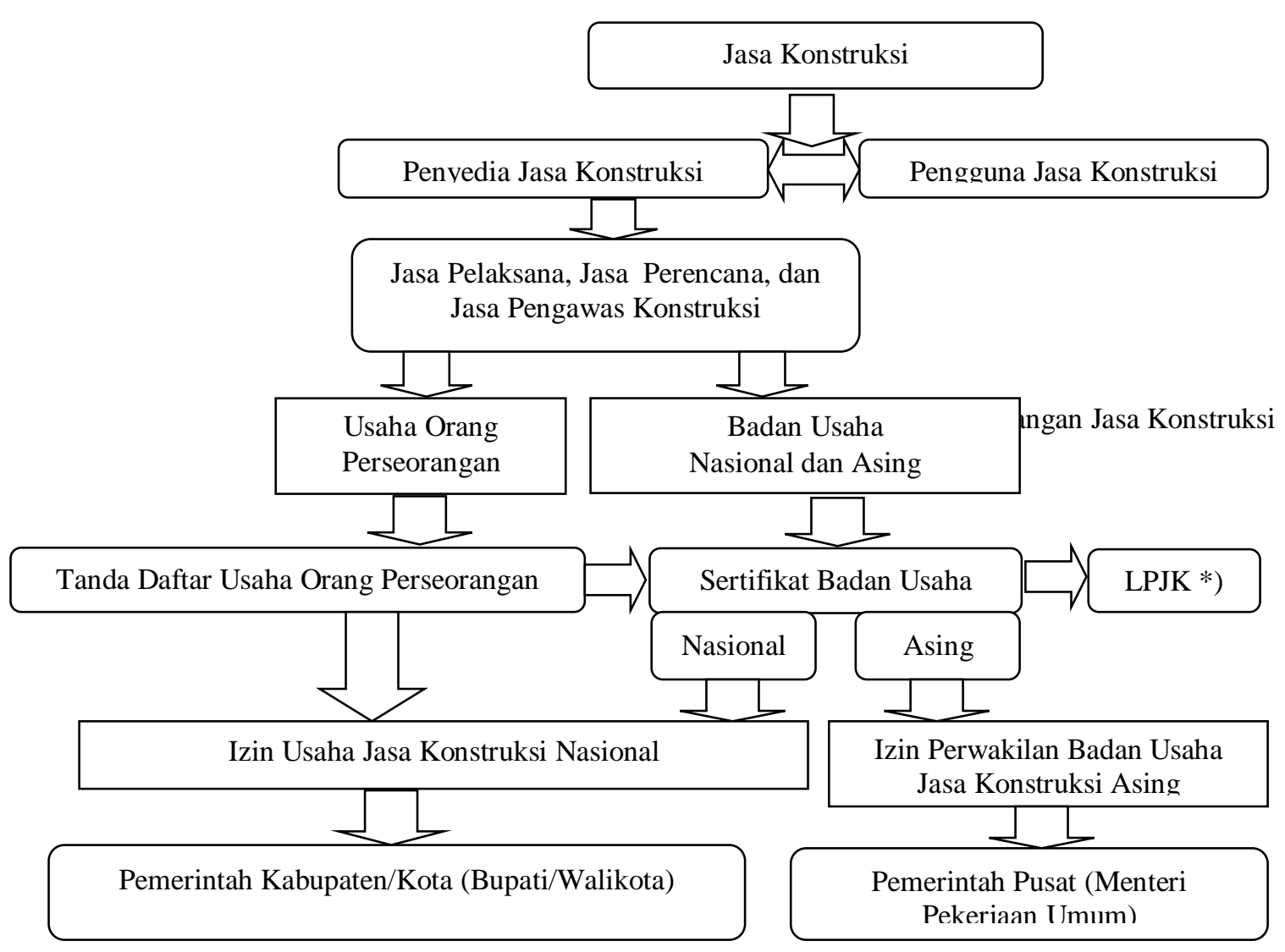

melakukan usaha jasa pelaksana konstruksi, jasa perencana konstruksi dan jasa pengawas konstruksi harus memiliki Tanda Daftar Usaha Orang Perseorangan, sedangkan setiap badan usaha baik nasional dan asing yang melakukan usaha jasa pelaksana konstruksi, jasa perencana konstruksi dan jasa pengawas konstruksi harus memiliki Sertifikat Badan Usaha. Tanda Daftar Usaha Orang Perseorangan dan Sertifikat Badan Usaha sebagai persyaratan permohonan izin usaha jasa konstruksi nasional atau izin perwakilan badan usaha jasa konstruksi asing. Berikut dibawah ini simpulan kegiatan usaha jasa konstruksi menurut undang-undang jasa konstruksi dalam bentuk skema adalah sebagai berikut: (tabel 5).

(2) Kegiatan usaha jasa konstruksi menurut undang-undang minyak dan gas bumi merupakan salah satu kegiatan usaha jasa penunjang minyak dan gas bumi yang 


\section{Skema Kegiatan Usaha Menurut Undang-Undang Minyak dan Gas}
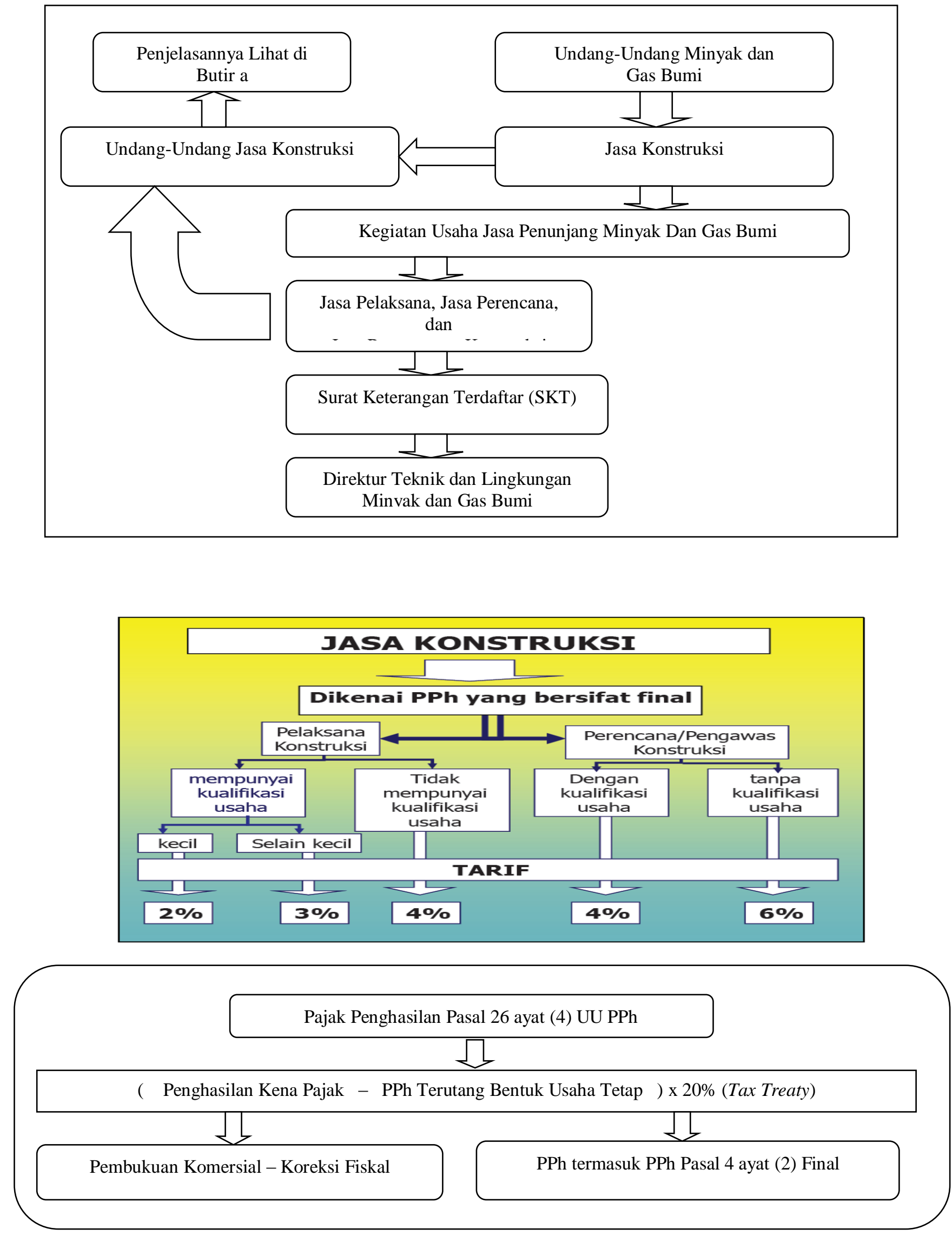
pelaksanaannya dilakukan sesuai ketentuan peraturan perundang-undangan di bidang jasa konstruksi dan bidang usaha tersebut terdiri atas: a) Usaha Jasa Perencanaan Konstruksi termasuk rancang bangun dan rekayasa (design engineering); b) Usaha Jasa Pelaksanaan Konstruksi termasuk E.ngineering, Procurement, and Construction (EPC), usaha instalasi, dan komisioning; dan c) Usaha Jasa Pengawasan Konstruksi. Apabila perseorangan dan perusahaan akan melaksanakan kegiatan usaha jasa konstruksi dibidang minyak dan gas bumi, maka perseorangan dan perusahaan tersebut diwajibkan memiliki Surat Keterangan Terdaftar (SKT). Berikut dibawah ini kesimpulan kegiatan usaha jasa konstruksi menurut menurut undang-undang minyak dan gas bumi dalam bentuk skema adalah sebagai berikut; (3).Kegiatan usaha jasa konstruksi menurut undang-undang perpajakan merupakan objek penghasilan atas kegiatan usaha jasa konstruksi yang dikenakan Pajak Penghasilan yang bersifat final. Berikut ini skema PPh Pasal 4 ayat (2) dan PPh Pasal 26 ayat (4).

Simpulan pada huruf a dan $b$ sebagaimana dijelaskan di atas untuk menjelaskan hasil penelitian pertama adalah proses bisnis jasa penunjang minyak dan gas bumi untuk kegiatan jasa konstruksi. Prinsip poses bisnis jasa penunjang minyak dan gas bumi untuk kegiatan jasa konstruksi menurut undang-undang jasa konstruksi dan undang-undang minyak dan gas bumi, adalah sama. Namun, yang perlu menjadi perhatian khusus adalah Surat Keterangan Terdaftar (SKT) dari Direktur Teknik dan Lingkungan Minyak dan Gas Bumi. Kesimpulan pada huruf c sebagaimana dijelaskan di atas untuk menjelaskan hasil penelitian kedua adalah aspek perpajakan atas jasa penunjang minyak dan gas bumi untuk kegiatan jasa konstruksi yang berdasarkan undang-undang perpajakan terkait dengan jasa konstruksi. Aspek perpajakan tersebut adalah sama dengan aspek perpajakan selain jasa penunjang minyak dan gas bumi, adalah Pajak Penghasilan Pasal 4 ayat (2) bersifat final dan Pajak Penghasilan Pasal 26 ayat (4) bagi Bentuk Usaha Tetap (BUT).

\section{DAFTAR PUSTAKA}

\section{Buku:}

Alsah, A. Sjarifuddin. 2002. Withholding Tax; Pemotongan/Pemungutan Pajak Penghasilan. Jakarta: Penerbit PT Kharisma Bintang Kreativitas Prima.

Boyd, et al. 1989. Marketing Reseach: Text and Cases. Boston: Irwin.

Budd Richard, et al. 1967. Content Analysis of Communication. New York: The Mac Millan Company.

Bungin, Burhan (Ed). 2006. Metodologi Penelitian Kualitatif. Ed. 1., Cet. 4. Jakarta: PT RajaGrafindo Persada.

Bungin, Burhan. 2003. Analisis Data Penelitian Kualitatif. Ed. 1, Cet. 1. Jakarta: PT RajaGrafindo Persada.

Denzin NK, Lincoln YS. 2000. The Discipline and Practice of Qualitative Research. Di dalam Denzin NK, Lincoln YS, eds. Handbook of Qualitative Research. Second Edition. Thousand Oaks: SAGE.

Gunadi. 2010. Panduan Komprehensif Pajak Penghasilan. Jakarta: PT Multi Utama Consultindo.

Hutagaol, J., Darussalam, dan Danny Septriady. 2006. Kapita Selekta Perpajakan. Jakarta: Penerbit Salemba Empat.

Kuncoro, Mudrajad. 2003. Metode Riset untuk Bisnis dan Ekonomi. Jakarta: Penerbit Erlangga.

McQuail, Denis. 2000. Mass Communication Theories, Fourth Edition. London: Sage Publication.

Rudi Rubiandini R.S., 2010. Mengenal Industri Migas dan Dana Bagi Hasil. Bandung: ITB Press.

Rusjidi, Muhammad. 2004. PPh; Pajak Penghasilan. Jakarta: Penebit Indeks.

Schmidt, D.J. 2007. Speaking of Language: On The Future of Hermeneutics. Research in Phenomenology 37. 
Santoso, Gempur. 2005. Metodologi Penelitian, Kuantitatif dan Kualitatif. Surabaya: Prestasi Pustaka Publisher.

Sumaryono, E. 1999. Hermeneutik: Sebuah Metode Filsafat, Edisi Revisi. Penerbit Kanisius.

Suryana. 2010. Metodologi Penelitian,"'Model Praktis Penelitian Kuantitatif dan Kualitatif" (Buku Ajar Perkuliahan). Jakarta: Uiversitas Pendidikan Indonesia.

Team Penyusun KPP Minyak dan Gas Bumi. 2012. Buku Panduan Kantor Pelayanan Pajak Minyak dan Gas Bumi; Proses Bisnis dan Aspek Perpajakan. Jakarta: Kantor Pelayanan Pajak Minyak dan Gas Bumi.

Tim Penyusun Direktorat Peraturan Perpajakan II. 2011. Oasis Pemotong/Pemungut PPh. Jakarta: Direktorat Jenderal Pajak.

Tim Penyusun STIAMI. 2012. Pedoman Penulisan Skripsi dan Artikel Ilmiah, Revisi 3. Jakarta: Sekolah Tinggi Ilmu Administrasi Mandala Indonesia.

Waluyo. 2007. Perpajakan Indonesia; Pembahasan sesuai dengan Ketentuan Perundang-undangan Perpajakan dan Aturan Pelaksanaan Perpajakan Terbaru. Edisi 7; Buku 1. Jakarta: Penerbit Salemba Empat.

Waluyo. 2007. Perpajakan Indonesia; Pembahasan sesuai dengan Ketentuan Perundang-undangan Perpajakan dan Aturan Pelaksanaan Perpajakan Terbaru. Edisi 7; Buku 2. Jakarta: Penerbit Salemba Empat.

Wimer, Roger, D., \& Dominick, Josep, R. 2000. Mass Media Research, Six Edition. New York: Wadsworth Publishing Company.

\section{Peraturan Minyak dan Gas Bumi:}

Undang Undang Nomor 22 Tahun 2001 tentang Minyak dan Gas Bumi.

Peraturan Pemerintah Nomor 55 Tahun 2009 tentang Perubahan Kedua atas Peraturan Pemerintah Nomor 35 Tahun 2004 tentang
Kegiatan Usaha Hulu Minyak dan Gas Bumi.

Peraturan Menteri Energi dan Sumber Daya Mineral Nomor 27 Tahun 2008 tentang Kegiatan Usaha Penunjang Minyak dan Gas Bumi.

Keputusan Direktur Jenderal Minyak dan Gas Bumi Nomor 15784.K/10/DJM.S/2010 tentang Pedoman Pemberian Surat Keterangan Terdaftar.

\section{Peraturan Jasa Konstruksi:}

Undang-undang Nomor 18 Tahun 1999 tentang Jasa Konstruksi.

Peraturan Pemerintah Nomor 92 Tahun 2010 tentang Perubahan Kedua atas Peraturan Pemerintah Nomor 28 Tahun 2000 tentang Usaha dan Peran Masyarakat Jasa Konstruksi.

Peraturan Menteri Pekerjaan Umum nomor 04/PRT/M/2011 tentang Pedoman Persyaratan Pemberian Izin Usaha Jasa Konstruksi Nasional.

Peraturan Menteri Pekerjaan Umum nomor 05/PRT/M/2011 tentang Pedoman Persyaratan Pemberian Izin Perwakilan Badan Usaha Jasa Konstruksi Asing.

Peraturan Lembaga Pengembangan Jasa Konstruksi Nomor 02 Tahun 2011 tentang Tata Cara Registrasi Ulang, Perpanjangan Masa Berlaku, Dan Permohonan Baru Sertifikat Badan Usaha Jasa Pelaksana Konstruksi.

Peraturan Lembaga Pengembangan Jasa Konstruksi Nomor 03 Tahun 2011 tentang Tata Cara Registrasi Ulang, Perpanjangan Masa Berlaku Dan Permohonan Baru Sertifikat Badan Usaha Jasa Perencana Dan Pengawas Konstruksi

\section{Peraturan Perpajakan:}

Undang-Undang Nomor 6 Tahun 1983 tentang Ketentuan Umum dan Tata Cara Perpajakan sebagaimana telah beberapa kali diubah terakhir dengan UndangUndang Nomor 16 Tahun 2009. 
Undang-Undang Nomor 7 Tahun 1983 tentang Pajak Penghasilan sebagaimana telah beberapa kali diubah terakhir dengan Undang-Undang Nomor 36 Tahun 2008.

Peraturan Pemerintah Nomor 40 Tahun 2009 tentang Perubahan atas Peraturan Pemerintah Nomor 51 Tahun 2008 tentang Pajak Penghasilan atas Penghasilan dari Usaha Jasa Konstruksi.

Peraturan Menteri Keuangan nomor 80/PMK.03/2010 tentang Perubahan atas Peraturan Menteri Keuangan Nomor 184/PMK.03/2007 tentang Penentuan Tanggal Jatuh Tempo Pembayaran dan Penyetoran Pajak, Penentuan Tempat Pembayaran Pajak, dan Tata Cara Pembayaran, Penyetoran dan Pelaporan Pajak, serta Tata Cara Pengangsuran dan Penundaan Pembayaran Pajak.

Peraturan Menteri Keuangan Nomor 153/PMK.03/2009 tentang Perubahan atas Peraturan Menteri Keuangan Nomor 187/PMK.03/2008 tentang Tata Cara Pemotongan, Penyetoran, Pelaporan, dan Penatausahaan Pajak Penghasilan atas Penghasilan dari Usaha Jasa Konstruksi.

Peraturan Menteri Keuangan Nomor 14/PMK.03/2011 tentang Perlakuan Perpajakan atas Penghasilan Kena Pajak Sesudah Dikurangi Pajak dari Suatu Bentuk Usaha Tetap.

\section{Jurnal, Makalah dan Slide:}

Agusta, Ivanovich. 2005. Makalah disampaikan dalam Lokakarya Metode Kualitatif, Fakultas Ekonomi Universitas Negeri Jakarta, Selasa 11 Oktober 2005.

Budiarta, Dewa Made. 2012. Slide "Overview KPP Migas".

Nasirwan. 2011. Telaah Pelanggaran Terhadap Etika Profesi Akuntan: Metode Hermeneutik. Jurnal Keuangan \& Bisnis. Volume 3 No. 1, Maret 2011.

Riduwan, Akhmad. Jurnal Penelitian, "Etika dan Perilaku Koruptif Dalam Praktik Manajemen Laba: Studi Hermeneutika”.

Riduwan, Akhmad. 2012. Jurnal Penelitian, "Realitas dalam Cermin Retak: Laba Akuntansi dalam Bingkai Penafsiran Praktisi Bisnis Non-Akuntan (Studi Hermeneutika-Kritis)".

Setiawan, Deddy Arief. 2011. Makalah Kebijakan Penghitungan Teknis PPh Pasal 26 ayat (4) Bentuk Usaha Tetap (BUT) Jasa Konstruksi.

\section{Webiste:}

www.kemenkeu.go.id

www.migas.esdm.go.id

www.pu.go.id

www.lpjk.net 